\title{
Photodegradation of Mutagens in Solvent-Refined Coal Liquids
}

\author{
D. R. Kalkwarf \\ D. L. Stewart \\ R. A. Pelroy \\ W. C. Weimer
}

April 1984

Prepared for the U.S. Department of Energy under Contract DE-AC06-76RLO 1830

Pacific Northwest Laboratory Operated for the U.S. Department of Energy by Battelle Memorial Institute

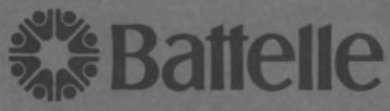




\title{
DISCLAIMER
}

This report was prepared as an account of work sponsored by an agency of the United States Government. Neither the United States Government nor any agency thereof, nor any of their employees, makes any warranty, express or implied, or assumes any legal liability or responsibility for the accuracy, completeness, or usefulness of any information, apparatus, product, or process disclosed, or represents that its use would not infringe privately owned rights. Reference herein to any specific commercial product, process, or service by trade name, trademark, manufacturer, or otherwise, does not necessarily constitute or imply its endorsement, recommendation, or favoring by the United States Government or any agency thereof. The views and opinions of authors expressed herein do not necessarily state or reflect those of the United States Government or any agency thereof.

\author{
PACIFIC NORTHWEST LABORATORY \\ operated by \\ BATTELLE \\ for the \\ UNITED STATES DEPARTMENT OF ENERGY \\ under Contract DE-AC06-76RLO 1830
}

Printed in the United States of America Available from

National Technical Information Service United States Department of Commerce 5285 Port Royal Road Springfield, Virginia 22161

NTIS Price Codes Microfiche A01

Printed Copy Pages Price

001-025

026-050

051-075

076-100

101-125

126-150

151-175

$176-200$

201-225

226-250

251-275

276-300

Codes

$\mathrm{A02}$

$\mathrm{A} 03$

A04

A05

A06

$\mathrm{A} 07$

A0B

A09

A010

A011

A012

A013 
PNL-4982

UC-90d

PHOTODEGRADATION OF MUTAGENS IN

SOLVENT-REFINED COAL LIQUIDS

D. R. Kalkwarf

D. L. Stewart

R. A. Pelroy

W. C. Weimer

April 1984

Prepared for

the U.S. Department of Energy

under Contract DE-AC06-76RLO 1830

Pacific Northwest Laboratory

Richland, Washington 99352 


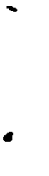

. 
SUMMARY

The purpose of this investigation was to evaluate any changes in the chemical composition and microbial mutagenicities of two representative solventrefined coal (SRC) liquids as a function of exposure time to sunlight and air. This information was desired to assess potential health hazards arising from yround spills of these liquids during production, transport and use. Results of microbial mutagenicity assays using Salmonella typhimurium TA98, conducted after exposure, showed that the mutagenicities of both an SRC-II fuel oil blend and an SRC-I process solvent decreased continuously with exposure time to air and that the decrease was accelerated by simultaneous exposure to simulated sunlight. The liquids were exposed as thin layers supported on surfaces of glass, paper, clay or aluminum; but the type of support had little effect on the results. The contrast between these results and the reported increases of mutagenesis in organisms exposed simultaneously to coal liquids and nearultraviolet light suggested that short-lived mutagenic intermediates, e.g., organic free radicals, were formed in the liquids during exposure to light.

The highest activities of microbial mutagenicity in the SRC liquids were found in fractions rich in amino polycyclic aromatic hydrocarbons (amino PAH). After a 36-hour exposure of the fuel oil blend to air in the dark, the mutagenicity of its amine-rich fraction was reduced by $65 \%$; whereas a 36 -hour exposure in the light reduced the mutagenicity of this fraction by $92 \%$. Similar rates of reduction in mutagenicity were achieved in exposures of the process solvent. The mutagenicities of other chemical fractions remained low during exposure. Analyses showed that most of the amine components of both liquids contained less than four aromatic rings and that their concentrations generally decreased with exposure time. These results indicate that the microbial mutagenicities of the two SRC liquids may be expected to gradually decrease if they are spilled out of doors, with the rate of decrease dependent on their access to air and sunlight. However, one cannot be sure that all of the potential health hazards of these materials are reduced by such exposures since the $\underline{s}$. typhimurium. TA98 test system has been reported to be relatively insensitive to potential mutagens in fractions of SRC liquids rich in neutral aromatic compounds. 
Electron spin resonance (ESR) measurements on the liquids showed free radical concentrations on the order of $5 \times 10^{16}$ unpaired spins per gram before exposure. In darkness, this concentration decreased continuously during exposure to air, paralleling the decrease in mutagenicities of the samples. In simulated sunlight, the concentration of paramagnetic species rapidly increased within the first few minutes of illumination and then decreased with continued exposure. This behavior suggested that organic free radicals were the major paramagnetic species, al though charge-transfer complexes may have al so been present. The ESR spectra were not sufficiently resolved to identify the chemical structure of the radicals; however, the lifetimes of the radicals and their spectroscopic line-widths and splitting factors were similar to those for radicals produced by photo-oxidation of 2-aminoanthracene, a typical amino-PAH compound. These observations suggest that the expression of mutagenic activity by the SRC liquids in S. typhimurium TA98 may involve conversion of their aminoPAH components to free radicals by oxidation and that these radicals and their parent amines are destroyed by extended illumination. 


\section{ACKNOWLEDGMENT}

The authors wish to acknowledge the careful work of $C$. Veverka, Jr. in separating the exposed and unexposed samples and in conducting the gaschromatographic analyses. 

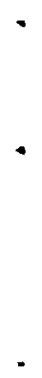

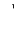




\section{CONTENTS}

SUMMARY.............................................. ii

ACKNOWLEDGMENT $\ldots \ldots \ldots \ldots \ldots \ldots \ldots \ldots \ldots \ldots \ldots \ldots \ldots \ldots \ldots \ldots \ldots \ldots \ldots \ldots \ldots \ldots \ldots \ldots$

INTRODUCTION . . . . . . . . . . . . . . . . . . . . . . . . . . . . . . . . 1

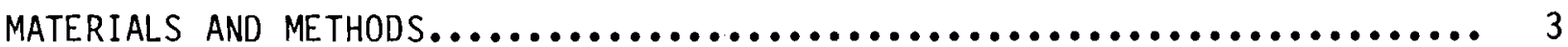

PRE-EXPOSURE HANDLING OF SAMPLES $\ldots \ldots \ldots \ldots \ldots \ldots \ldots \ldots \ldots \ldots \ldots \ldots \ldots \ldots$

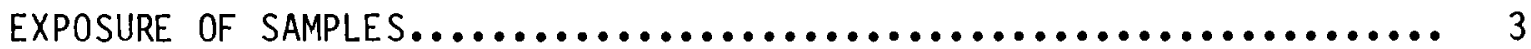

FRACTIONATION OF EXPOSED SAMPLES...................... 5

MUTAGENICITY ASSAYS................................ 5

CHARACTERIZATION OF SAMPLE COMPONENTS.................... 6

RESULTS................................................ 9

CHANGES IN MICROBIAL MUTAGENICITY DUE TO EXPOSURE .............. 9

CHANGES IN CHEMICAL COMPOSITION DUE TO EXPOSURE................ 14

DISCUSSION............................................... 27

CONCLUSIONS............................................ 31

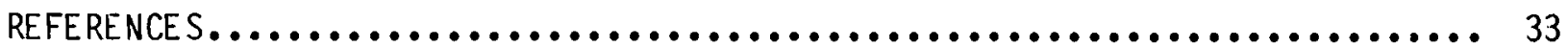


FIGURES

1 Apparatus for Exposing Samples to Simulated Sunlight............ 4

2 Microbial Mutagenicities of Amine-Rich, S-2 Fractions from Samples of SRC-II Fuel $0 i 1$ Blend Exposed to Air on Different Supports Either in Darkness or in $1.37 \mathrm{~kW} / \mathrm{m}^{2}$ of Simulated Sunlight for Various Time Periods.

3 Microbial Mutagenicities of Amine-Rich, S-2 Fractions from Samples of SRC-I Process Solvent Exposed to Air on Different Supports Either in Darkness or in $1.37 \mathrm{~kW} / \mathrm{m}^{2}$ of Simulated Sunlight for Various Time Periods...........................

4 Disappearance of Representative Amines in the S-2 Fraction of SRC-II Fuel $0 i 1$ Blend as a Function of Exposure Time to Air on Paper.

5 Disappearance of Representative Amines in the S-2 Fraction of SRC-I Process Solvent as a Function of Exposure Time to Air on Paper.

6 Electron Spin Resonance Spectra of (a) SRC-II Fuel 0 il Blend and (b) SRC-I Process Solvent as 10\% Solutions in Toluene......... 20

7 Radical Concentrations in $10 \%$ Solutions of Coal Liquids in Toluene as a Function of Exposure Time to Air in Simulated Sunl ight.

8 Radical Concentration in a 10\% Solution of SRC-I Process Solvent in Toluene as a Function of Exposure Time to Air in Simulated Suntight............................................

9 Concentrations of Paramagnetic Species in 10\% Solutions of SRC Liquids in Toluene as a Function of Exposure Time to Air in Darkness.

10 Concentrations of 2-Aminoanthracene and Its Free-Radical Product as Functions of Time in Air and Simulated Sunlight.............. 25

11 Electron Spin Resonance Spectrum of the Free Radical Formed by Photolysis of 2-Aminoanthracene in Air and Simulated Sunlight..... 25 


\section{TABLES}

1 Weight Percentages and Microbial Mutagenicities (TA98) of Fractions Separated from SRC Liquids..........................

2 Microbial Mutagenicities of Amine-Rich, S-2 Fractions from Samples of SRC-II Fuel $0 i 1$ Blend Exposed to Air on Different Supports Either in the Därk or in $1.37 \mathrm{~kW} / \mathrm{m}^{2}$ of Simulated Sun1ight for Various Time Periods.........................

3 Microbial Mutagenicities of Amine-Rich, S-2 Fractions from Samples of SRC-I Process Solvent Exposed to Air on Different Supports Either in Darkness or in $1.37 \mathrm{~kW} / \mathrm{m}^{2}$ of Simulated Sunlight for Various Time Periods.

4 Microbial Mutagenicities of Fractions 0ther than S-2 from Samples of SRC-II Fuel 0i1 Blend Exposed to Air on Different Supports Either in Darkness or in $1.37 \mathrm{~kW} / \mathrm{m}^{2}$ of Simulated Sunlight for Various Time Periods............................

5 Microbial Mutagenicities of Fractions 0ther than S-2 from Samples of SRC-I Process Solvent Expgsed to Air on Different Supports in Darkness or in $1.37 \mathrm{~kW} / \mathrm{m}^{2}$ of Simulated Sunlight for Various Time Periods.

Weight Distributions of Fractions in SRC-II Fuel $0 i 1$ Blend Exposed to Air on Different Supports in Darkness or $1.37 \mathrm{~kW} / \mathrm{m}^{2}$ of Simulated Sunlight for Various Time Periods...................

7 Weight Distributions of Fractions in SRC-I Process Solvent Exposed to Air on Different Supports in Darkness or in $1.37 \mathrm{~kW} / \mathrm{m}^{2}$ of Simulated Sunlight for Various Periods of Time................

8 Concentrations of Components Identified in the Amine-Rich, S-2 Fractions of SRC-II Fuel,0il Blend Exposed to Air on Paper in Darkness or in $1.37 \mathrm{~kW} / \mathrm{m}^{2}$ of Simulated Sunlight for Various Time Periods...........................................

9 Concentrations of Components Identified in the Amine-Rich, S-2 Fractions of SRC-I Process Solvent Exposed to Air on Paper in Darkness or in $1.37 \mathrm{~kW} / \mathrm{m}^{2}$ of Simulated Sunlight for Various Time Periods

11 Concentrations of Organic Free Radicals in Fractions from Samples of Untreated Coal Liquids.

12 Concentrations of Organic Free Radicals in the Amine-Rich, S-2 Fractions from Samples of Coal Liguids Exposed to Air on Glass or Paper in Darkness or in $1.37 \mathrm{~kW} / \mathrm{m}^{2}$ of Simulated Sunlight 
INTRODUCTION

The development of coal liquefaction processes has caused concern about the potential toxicity of liquefaction products. Some of these liquids have been found to be mutagenic in Salmonella typhimurium TA98 and to initiate tumor formation in mice (Wilson et al. 1980; Pelroy and Petersen 1981; Pelroy and Wilson 1981; Mahlum and Wilson 1983; Mahlum 1983). Moreover, the mutagenicities of some coal liquids and other materials containing polycyclic aromatic compounds have been shown to increase during exposure to near-ultraviolet light (Larson et a1. 1977; Barnhart and Cox 1980; Strniste and Brake 1981; Strniste and Chen 1981; Chen and Strniste 1982; Strniste et al. 1982a, 1982b; Selby et al. 1983 ). Such exposures could occur if coal liquids were spilled out of doors at a production plant or during transport to a combustion site.

The purpose of this investigation was to evaluate any changes in the chemical composition and microbial mutagenicities of representative solvent-refined coal (SRC) liquids as a function of exposure time to sunlight and air. This information was desired for assessing potential health hazards arising from ground spills of these liquids during production, transport and use. Although microbial assays do not always accurately predict the mutagenicities of materials in mammalian cells, they do provide a relatively inexpensive assessment of genotoxicity.

Two coal liquids were selected for study: an SRC-II fuel oil blend and an SRC-I process solvent. These liquids represent pilot-plant-scale materials from single-stage, coal-liquefaction processes and are not necessarily representative of materials which may eventually be produced commercially. Mutagens were highly diluted in these materials, so that concentration by means of fractionation was necessary to evaluate their mutagenicities precisely. Thus, the plan for the investigation was to (1) expose each liquid to air in the dark or in simulated sunlight under conditions representative of those expected for potential spills, (2) separate the products into fractions based on chemical class, (3) evaluate the mutagenicities of these fractions as a function of exposure time and (4) determine the chemical basis for any changes in mutagenicity by more-detailed analyses. 


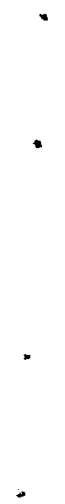


PRE-EXPOSURE HANDLING OF SAMPLES

An SRC-I I fuel oil blend was obtained from the SRC-II pilot plant at Fort Lewis, Washington. It was prepared from components produced at the site and consisted of 2.9 parts of micdle distillate (b.p. $=350$ to $550^{\circ} \mathrm{F}$ ) mixed with 1 part of heavy distillate (b.p. $=550$ to $850^{\circ} \mathrm{F}$ ). The mixture was stored at $4^{\circ} \mathrm{C}$ in Teflon-lined, stainless-steel containers, blanketed with nitrogen gas. Analyses for the major components in this material have been reported earlier (Wright and Weimer 1984).

SRC-I process solvent was obtained from the SRC-I pilot plant at Wilsonville, Alabama. It was stored in the same manner as described above. Analyses for the major components in this material have also been reported (Wright and Weimer 1984).

EXPOSURE OF SAMPLES

Samples of the SRC liquids were exposed to air for measured periods of time in the dark and in simulated sunlight, using the apparatus shown in Figure 1. This apparatus consisted of an exposure chamber, a thermoelectric cooling plate and a source of simulated sunlight. The exposure chamber was a glass dish with a quartz cover plate which transmitted the complete solar spectrum. Several different materials were used to support the SRC liquids in the dish in order to test for catalytic effects of the support surface during exposure. In addition to the glass bottom of the dish itself, Whatman No. 1 filter paper, bentonite clay particles, 100 to 500 um in size, and a plate of aged aluminum were used as supports. The latter three materials were selected as representative of the cellulose, soil and metal surfaces that might be encountered in actual spills. Samples were spread thinly on these supports in order to expose them uniformly to air and simulated sunlight. A 750-mg portion of liquid was spread over the $24-\mathrm{cm}^{2}$ area of the support, and its temperature was maintained at $23^{\circ} \mathrm{C}$ by placing the exposure chamber on the surface of the c001 plate, model SK 12, manufactured by Thermoelectronics Unlimited. After the sample was placed in the dish, the cover plate was attached with Teflon tape to form an airtight seal. 


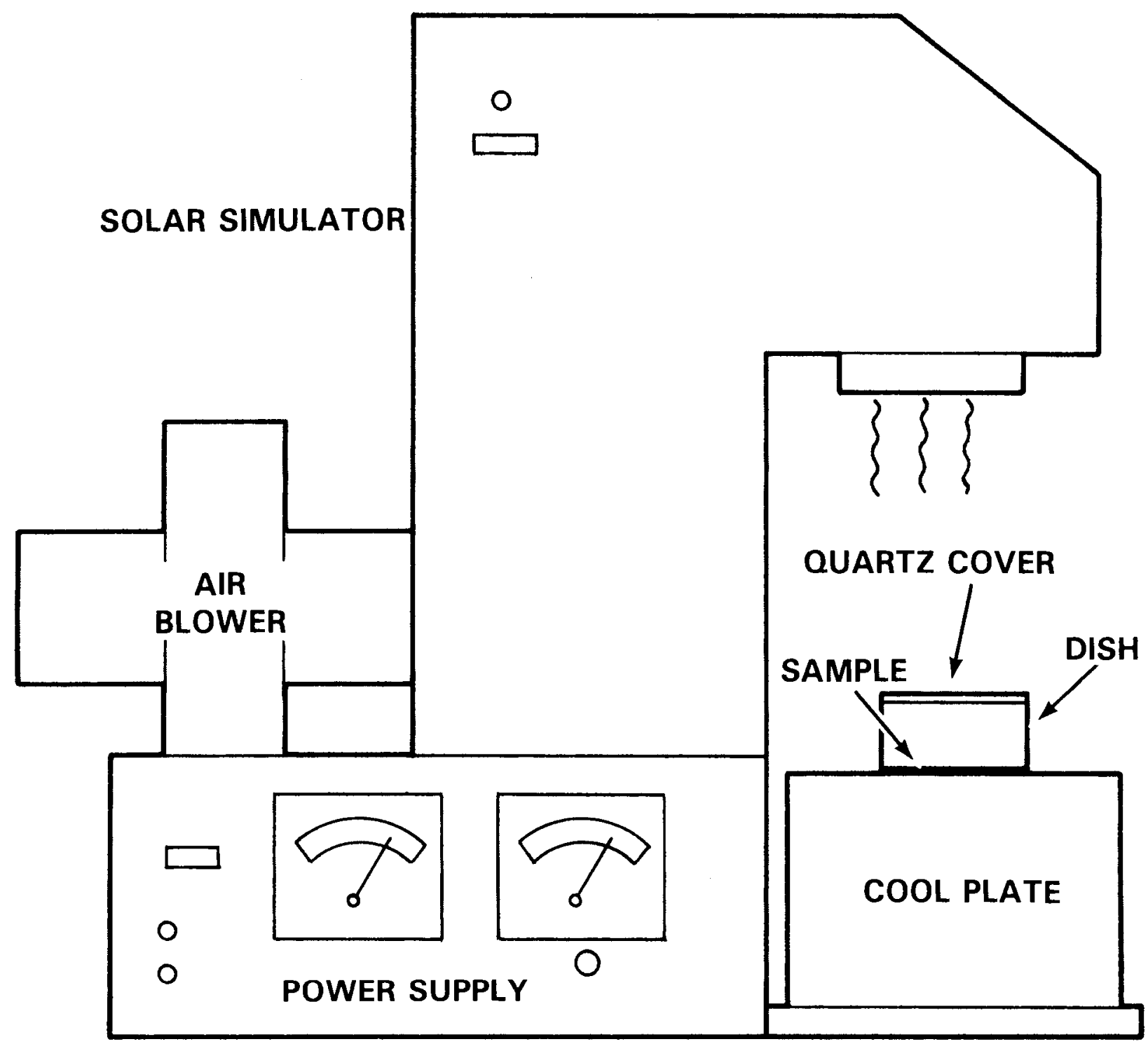

FIGURE 1. Apparatus for Exposing Samples to Simulated Sunlight

Simulated sunlight was supplied by an Oriel solar simulator, model 6720 . The spectrum of emitted light was adjusted to that of sunlight striking the earth's surface at $90^{\circ}$ by using optical filters supplied with this instrument. The intensity of light was measured with an Eppley pyranometer, model PSP, and was adjusted to a value of $1.37 \mathrm{~kW} / \mathrm{m}^{2}$, the maximum intensity of sunlight striking the earth's surface (Stair and Ellis 1968). 


\section{FRACTIONATION OF EXPOSED SAMPLES}

Following exposure, each sample was extracted from its support, first with three $5-\mathrm{cm}^{3}$ portions of methylene chloride, then with three $5-\mathrm{cm}^{3}$ portions of methyl alcohol. Distilled-in-glass solvents, prepared by Burdick and Jackson Inc., were used in each case. The extracts were combined, and the components were separated into chemical-class fractions by column chromatography (Later et a1. 1981). A sample was first separated on alumina into four major fractions: (A-1) aliphatic hydrocarbons, (A-2) neutral monocyclic and polycyclic aromatic compounds, (A-3) nitrogen-containing aromatic compounds and (A-4) monocyclic and polycyclic phenols. The nitrogen-containing compounds were then further separated by column chromatography on silica gel into three fractions: (S-1) heterocylic compounds containing secondary nitrogen atoms, (S-2) monocyclic and polycyclic aromatic amines (amino-PAH), and (S-3) heterocyclic compounds containing tertiary nitrogen atoms. Following separation, a portion of each fraction was dissolved in dimethyl sulfoxide and assayed for mutagenicity. The remainder of each fraction was dissolved in methylene chloride for chemical analysis. During storage, all solutions were kept at $-13^{\circ} \mathrm{C}$ under an atmosphere of nitrogen gas.

\section{MUTAGENICITY ASSAYS}

Standard plate-incorporation mutagenicity assays were performed using $\underline{S}$. typhimurium TA98 (Ames et al. 1975). Samples were applied as solutions in dimethyl sulfoxide. Assays were run both with and without activation by S-9 enzymes prepared from liver homogenates of Aroclor-injected rats. Optimum concentrations of the S- 9 enzymes in the assays were established in preliminary experiments. Positive controls for the assays included standard solutions of 2-aminoanthracene and benzo[a]pyrene. Background frequencies of reversion were measured with aliquots of dimethyl sulfoxide. Revertant colonies on the petri plates were counted electronically with a Biotran II automated colony counter.

The mutagenic activity of a chemical fraction was expressed as the number of revertant colonies of $\underline{S}$. typhimurium TA98 observed per $\mu \mathrm{g}$ of test material. This ratio was estimated by linear-regression analysis of the dose-response data. A positive test was considered to be one showing twice the the background 
frequency of revertant colonies. Data were averaged from at least four doses which showed a correlation coefficient of 0.8 or greater and an intercept at zero dose within $20 \%$ of the background for the day.

CHARACTERIZATION OF SAMPLE COMPONENTS

Solutions of fractions showing high mutagenic activity were analyzed with a Carlo Erba series 4160 gas chromatograph fitted with an electron-capture detector. Fractions rich in amino-PAH were treated with pentafluoropropionic anhydride to convert those components to the corresponding amides (Later et a1. 1982). The fluorine-substituted amides gave larger signals than the original amines and were, thus, more readily distinguishable from other components in the fractions. The solutions were injected directly onto a silicone-bonded quartz capillary column, type DB-5, prepared by S\&J Inc. The injection temperature was $40^{\circ} \mathrm{C}$, and the temperature program used increased the column temperature by $8^{\circ} \mathrm{C}$ per minute to $200^{\circ} \mathrm{C}$, and then, by $2^{\circ} \mathrm{C}$ per minute, to $260^{\circ} \mathrm{C}$. The retention times of the components were then compared with those for a group of 16 aromatic amine standards treated in the same way. Concentrations of these amines in the samples were calculated from the area of the identified peak, the response factor of the detector for that component and the weight fraction of $S-2$ material in the coal liquid. Some derivatized fractions were also analyzed with a Hewlett-Packard gas chromatograph/mass spectrometer, model 5982 A.

Solutions of the unfractionated coal liquids and their chemical-class fractions were analyzed for paramagnetic species, such as organic free radicals, by electron spin resonance (ESR) spectrometry. A Varian spectrometer, model E-1600, was used with a 12-inch magnet whose field was modulated at $100 \mathrm{kHz}$. Some solutions were examined both before and after exposure to simulated sunlight in the apparatus shown in Figure 1. They were exposed as layers, $0.2 \mathrm{~mm}$ in depth. Each sample was passed through a Teflon filter with 0.22- $\mu \mathrm{m}$ pores, Millipore type FGLP, before being transferred to a quartz sample container in the spectrometer. The microwave cavity of the spectrometer contained a slotted window, and some samples were examined while illuminated with light from a xenon lamp, Eimac type 150x8R, that was filtered with Pyrex glass to simulate the spectrum of sunlight. 
The ESR signals from the samples were displayed graphically as first derivatives of the absorption spectra, and the concentrations of radicals giving rise to these signals were measured by double integration of the spectra, using a moment balance (Alger 1968). The system was calibrated with a standard solution of the stable free radical, $\alpha, \alpha^{\prime}$-diphenylpicrylhydrazyl $(\mathrm{DPPH})$ in mineral oil. The concentration of radicals in this standard was evaluated from its physical density, its optical absorption at $520 \mathrm{~nm}$ and the molar absorptivity of DPPH, $1.15 \times 10^{4} \mathrm{~L} \mathrm{~mol}^{-1} \mathrm{~cm}^{-1}$ (Henglein et al. 1957). For day-to-day calibrations of the spectrometer, a powdered mixture of DPPH in sodium sulfate was used. The spectroscopic splitting factor (i.e., g-value) and hyperfine splitting of the resonance lines were also examined to help identify the chemical structures of the paramagnetic species.

Since ESR signals can arise from paramagnetic transition-metal compounds as well as from organic free radicals and charge-transfer complexes, the concentrations of several transition metals in the coal liquids were determined by energy-dispersive $X$-ray fluorescence spectrometry. The samples were analyzed with a Kevex spectrometer, model 810a, using $\mathrm{Zr}$ and $\mathrm{Ag}$ secondary sources. The procedure followed was that described by Sanders et al. (1983). 

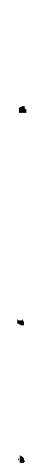

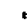


CHANGES IN MICROBIAL MUTAGENICITY DUE TO EXPOSURE

The S-2 fractions of both SRC-II fuel oil blend and SRC-I process solvent were found to contain the highest mutagenic activity, as shown in Table 1. These fractions should contain all of the monocyclic and polycyclic aromatic amines in the coal liquids. Exposure of the unfractionated liquids to air decreased the mutagenicities of their S-2 fractions, and the process was acce1erated by simultaneous exposure to simulated sunlight. Table 2 lists the mutagenicities of S-2 fractions from the SRC-II fuel oil blend as a function of exposure. These results, plotted in Figure 2, indicate that the composition and texture of the support had little effect on the decrease in mutagenicities. Mutagenicity was observed only if the activating enzyme, S-9, was added to the fractions before they were assayed. Exposures of SRC-I process solvent were conducted only on glass and paper supports, but similar effects were observed. These results are shown in Table 3 and Figure 3.

TABLE 1. Weight Percentages and Microbial Mutagenicities (TA98) of Fractions Separated from SRC Liquids

\begin{tabular}{|c|c|c|c|c|}
\hline \multirow[b]{2}{*}{ Fraction } & \multicolumn{2}{|c|}{ SRC-I I Fuel 0il Blend } & \multicolumn{2}{|c|}{ SRC-I Process Solvent } \\
\hline & Weight $\%$ & $\begin{array}{c}\text { Mutagenicity } \\
\text { (revertants } / \mu g \pm S E)\end{array}$ & Weight $\%$ & $\begin{array}{c}\text { Mutagenicity } \\
\text { (revertants } / \mu g \pm S E)\end{array}$ \\
\hline$\overline{\text { (Crude) }{ }^{(a)}}$ & $\overline{(100)}$ & $(7 \pm 1)$ & $\overline{(100)}$ & $(11 \pm 4)$ \\
\hline$A-1$ & 28 & 0 & 21 & 0 \\
\hline$A-2$ & 28 & 0 & 37 & 0 \\
\hline$S-1$ & 5.6 & 0 & 8.8 & 0 \\
\hline$S-2$ & 1.3 & 283 & 1.7 & 235 \\
\hline$S-3$ & 4.4 & 4 & 5.5 & 22 \\
\hline$A-4$ & 26 & 0 & 24 & 0 \\
\hline Recovery & 93 & & 98 & \\
\hline
\end{tabular}

(a) Wright and Weimer, 1984 
TABLE 2. Microbial Mutagenicities (revertants/ $\mu \mathrm{g}$ ) of Amine-Rich, S-2 Fractions from Samples of SRC-II Fuel 0il Blend Exposed to Air on Different Supports Either in the Dark or in $1.37 \mathrm{~kW} / \mathrm{m}^{2}$ of Simulated Sunlight for Various Time Periods

\begin{tabular}{|c|c|c|c|c|c|c|c|c|}
\hline \multirow{2}{*}{$\begin{array}{l}\text { Time } \\
(\mathrm{hr}) \\
\end{array}$} & \multicolumn{2}{|c|}{$\begin{array}{l}\text { Glass } \\
\text { Support }\end{array}$} & \multicolumn{2}{|c|}{$\begin{array}{l}\text { Paper } \\
\text { Support }\end{array}$} & \multicolumn{2}{|c|}{$\begin{array}{c}\text { Clay } \\
\text { Support }\end{array}$} & \multicolumn{2}{|c|}{$\begin{array}{l}\text { Aluminum } \\
\text { Support }\end{array}$} \\
\hline & Dark & Light & Dark & Light & Dark & Light & Dark & Light \\
\hline 0 & 283 & 283 & 283 & 283 & 283 & 283 & 283 & 283 \\
\hline 9 & 175 & 96 & 166 & 79 & 157 & 80 & 169 & 90 \\
\hline 18 & 151 & 66 & 145 & 30 & 128 & 43 & 134 & 72 \\
\hline 36 & 84 & 33 & 108 & 12 & 115 & 37 & 95 & 28 \\
\hline
\end{tabular}

TABLE 3. Microbial Mutagenicities (revertants/ $\mu$ ) of Amine-Rich, S-2 Fractions from Samples of SRC-I Process Solvent Exposed to Air on Different Supports Either in Darkness or in $1.37 \mathrm{~kW} / \mathrm{m}^{2}$ of Simulated Sunlight for Various Time Periods

\begin{tabular}{|c|c|c|c|c|}
\hline $\begin{array}{l}\text { Time } \\
(h r)\end{array}$ & $\frac{\text { Glass }}{\text { Dark }}$ & $\frac{\text { Support }}{\text { Light }}$ & $\frac{\text { Paper }}{\text { Dark }}$ & Support \\
\hline 0 & 235 & 235 & 235 & 235 \\
\hline 9 & 42 & 44 & 125 & 125 \\
\hline 18 & 44 & 26 & 96 & 50 \\
\hline 36 & 55 & 29 & 74 & 6 \\
\hline
\end{tabular}

Exposure caused little to no increase in the mutagenicities of fractions other than S-2, as can be seen from Tables 4 and 5 . The A-1, A-2 and A-4 fractions, containing the aliphatic compounds, the neutral aromatic compounds and the aromatic phenols, showed no measurable mutagenicity before exposure and none after 36 hours in air and sunlight. The S-1 fractions of both liquids, containing heterocyclic compounds with secondary nitrogen atoms, were nonmutagenic before exposure, but the fraction from the fuel oil blend showed a slight mutagenicity after 36 hours of exposure. The S-3 fractions of both liquids were slightly mutagenic before exposure and slightly mutagenic afterwards. The S-3 fraction of the fuel oil blend increased somewhat in mutagenicity as a result of a 36-hour exposure, whereas the S-3 fraction of the process solvent 


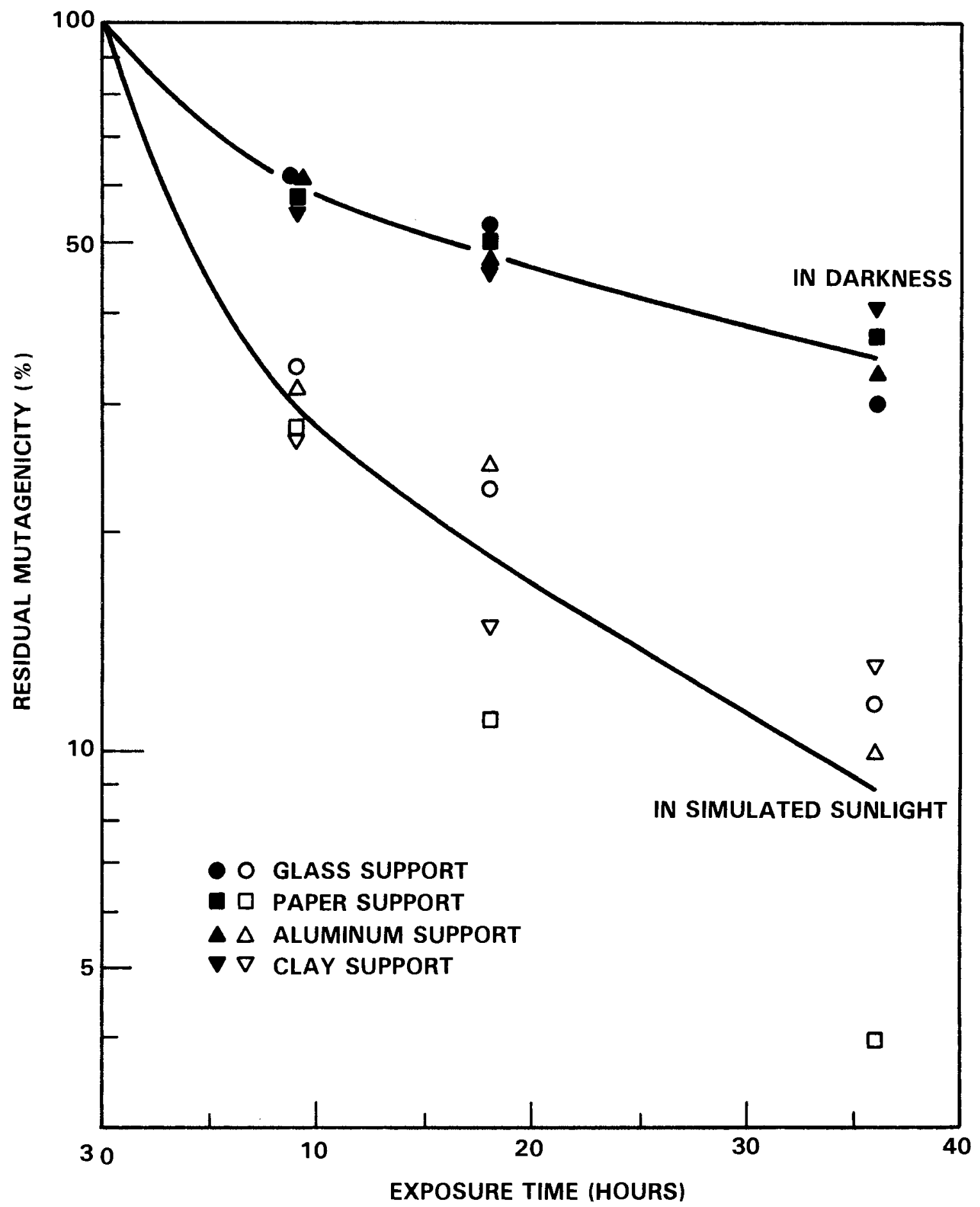

FIGURE 2. Microbial Mutagenicities of Amine-Rich, S-2 Fractions from Samples of SRC-II Fuel 0il Blend Exposed to Air on Different Supports Either in Darkness or in $1.37 \mathrm{~kW} / \mathrm{m}^{2}$ of Simulated Sunlight for Various Time Periods 


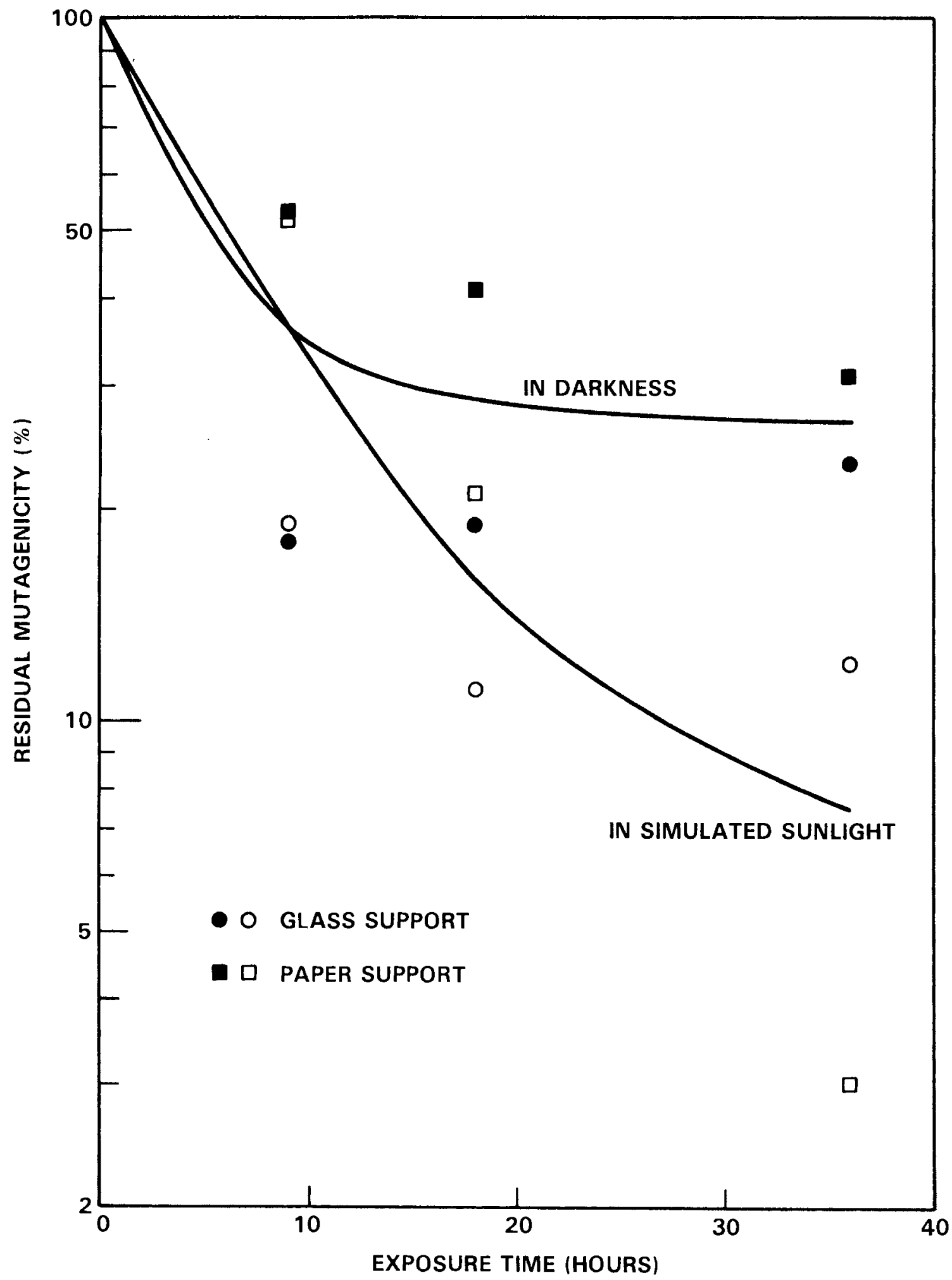

FIGURE 3. Microbial Mutagenicities of Amine-Rich, S-2 Fractions from Samples of SRC-1 Process Solvent Exposed to Air on Different Supports Either in Darkness or in $1.37 \mathrm{~kW} / \mathrm{m}^{2}$ of Simulated Sunlight for Various Time Periods 
TABLE 4. Microbial Mutagenicities of Fractions 0ther than S-2 from Samples of SRC-II Fuel 0il Blend Exposed to Air on Different Supports Either in Darkness or in $1.37 \mathrm{~kW} / \mathrm{m}^{2}$ of Simulated Sunlight for Various Time Periods

\begin{tabular}{|c|c|c|c|c|c|}
\hline \multirow[b]{2}{*}{ Treatment } & \multicolumn{5}{|c|}{ Mutagenicity (revertants $/ \mathrm{\mu g}$ ) } \\
\hline & $A-1$ & $A-2$ & S-1 & $5-3$ & $A-4$ \\
\hline $0^{(a)}$ & 0 & 0 & 0 & 4 & 0 \\
\hline 9LG & 0 & 0 & & & 0 \\
\hline $18 L G$ & 0 & 0 & & & 0 \\
\hline $36 D G$ & & & 3 & 18 & \\
\hline $36 \mathrm{DP}$ & & & 3 & 17 & \\
\hline $36 D C$ & & & 4 & 24 & \\
\hline 36DA & & & 2 & 20 & \\
\hline $36 L G$ & 0 & 0 & 0 & 6 & 0 \\
\hline $36 \mathrm{LP}$ & & & 0 & 13 & \\
\hline $36 \mathrm{LC}$ & & & 1 & 15 & \\
\hline $36 \mathrm{LA}$ & & & 1 & 19 & \\
\hline
\end{tabular}

(a) Number of exposure hours in darkness (D) or light (L) on glass (G), paper $(P)$, clay (C) or aluminum (A)

TABLE 5. Microbial Mutagenicities of Fractions 0ther than S-2 from Samples of SRC-I Process Solvent Exposed to Air on Different Supports in Darkness or in $1.37 \mathrm{~kW} / \mathrm{m}^{2}$ of Simulated Sunlight for Various Time Periods

\begin{tabular}{|c|c|c|c|c|c|}
\hline \multirow[b]{2}{*}{ Treatment } & \multicolumn{5}{|c|}{ Mutagenicity (revertants/ug) } \\
\hline & $A-1$ & $A-2$ & $5-1$ & $5-3$ & $A-4$ \\
\hline $0(a)$ & 0 & 0 & 0 & 22 & 0 \\
\hline $360 G$ & 0 & 0 & 0 & 15 & 0 \\
\hline $36 \mathrm{LG}$ & 0 & 0 & 0 & 3 & 0 \\
\hline
\end{tabular}

(a) Number of exposure hours in darkness (D) or light (L) on glass (G) or paper (P) 
decreased in mutagenicity during that time period. In both cases, the changes in mutagenicity were small compared to those found in the S-2 fractions.

CHANGES IN CHEMICAL COMPOSITION DUE TO EXPOSURE

There was no clear pattern of change in the weight distribution of fractions from the coal liquids following exposure to air. The distributions and recoveries are listed in Tables 6 and 7. The data for the fuel oil blend suggested a gradual increase in the S-1 fraction with exposure time, but this pattern was not seen in data for the $S-1$ fraction of process solvent.

Gas chromatography, gas chromatography/mass spectrometry and ESR spectrometry were used to determine the chemical basis for the decrease in mutagenicity of the S-2 fractions. Over 100 components of the derivatized amine-rich fractions were separated by gas chromatography. Concentration data for those identified in the fuel oil blend and process solvent after exposure to air and sunlight on paper are shown in Tables 8 and 9 . Several unidentified components in each sample gave rise to chromatographic peaks with larger areas than those identified. The values in these tables should therefore be regarded as representative rather than as a complete analysis of the samples. Generally, the concentrations of both the identified amines and the unidentified components in the S-2 fractions decreased with exposure time, and the rates of decrease were enhanced by simultaneous exposure to simulated sunlight. Data for representative components in the coal liquids are plotted versus time in Figures 4 and 5 . Comparison of these data with those in Figures 2 and 3 shows a marked similarity between the rate of decrease in mutagenicity of the coal liquids with exposure time and the rate of decrease in concentrations of the selected amines in these liquids. Comparison of chromatographic peak areas with their columnretention times indicates that the bulk of the components in the amine-rich, S-2 fractions of both liquids contained less than four aromatic rings. This was confirmed by gas chromatography/mass spectrometry.

Electron spin resonance (ESR) signals were detected in both SRC liquids, indicating the presence of compounds with unpaired electrons (e.g., organic free radicals, organic charge transfer complexes or paramagnetic organometallic compounds). The ESR spectra for solutions of the coal liquids in toluene are shown in Figure 6. Each signal consisted of a single absorption band centered 
TABLE 6. Weight Distributions of Fractions in SRC-I I Fuel 0il Blend Exposed to Air on Different Supports in Darkness or $1.37 \mathrm{~kW} / \mathrm{m}^{2}$ of Simulated Sunlight for Various Time Periods. (All values in percent.)

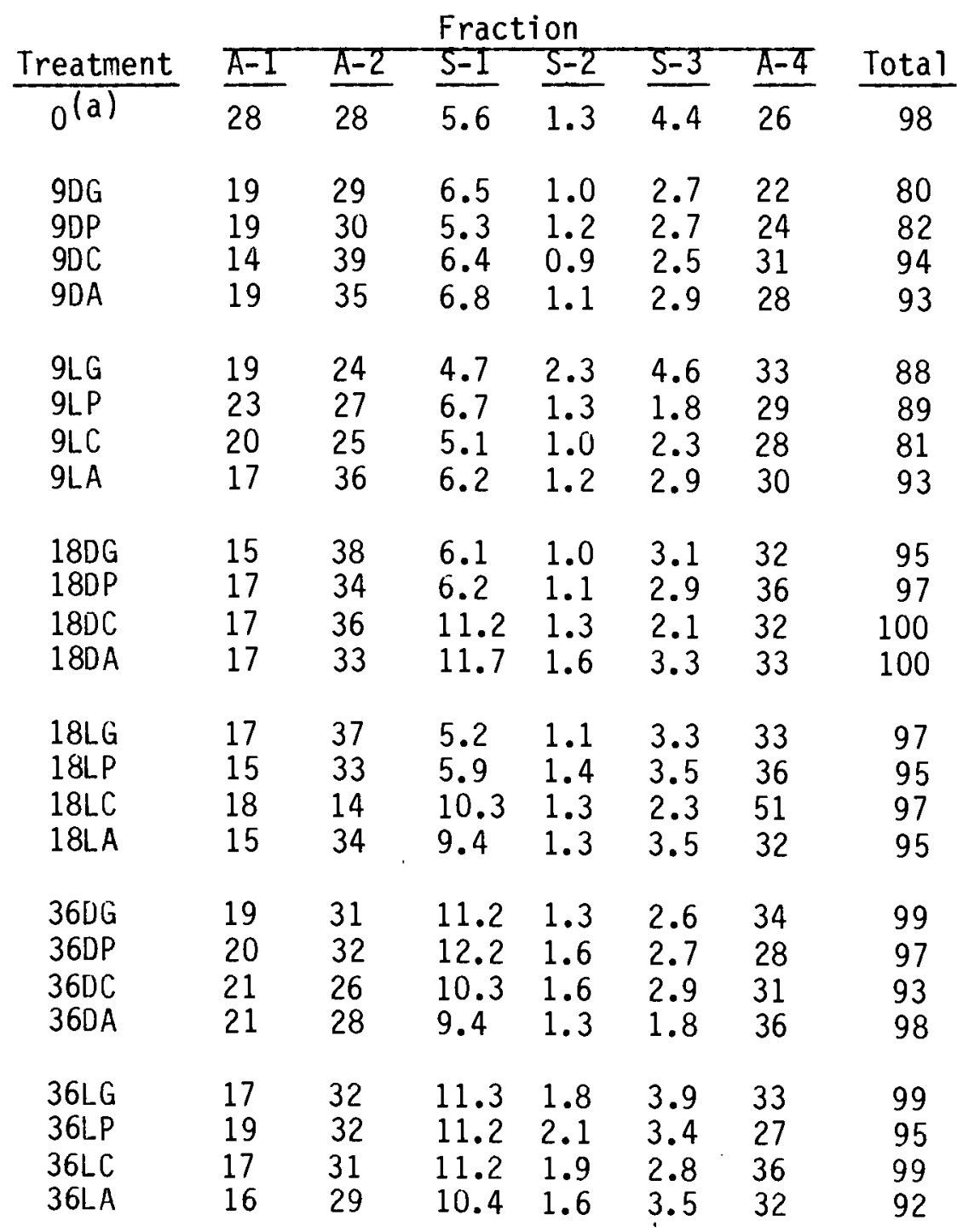

(a) Number of exposure hours that the sample was exposed to air in darkness (D) or in light $(L)$ on glass $(G)$, paper $(P)$, clay $(C)$ or aluminum $(A)$ 
TABLE 7. Weight Distributions of Fractions in SRC-I Process Solvent Exposed to Air on Different Supports in Darkness or in $1.37 \mathrm{~kW} / \mathrm{m}^{2}$ of Simulated Sunlight for Various Periods of Time. (All values in percent.)

\begin{tabular}{|c|c|c|c|c|c|c|c|}
\hline \multirow[b]{2}{*}{ Treatment } & \multicolumn{6}{|c|}{ Fraction } & \multirow[b]{2}{*}{ Total } \\
\hline & $A-1$ & $A-2$ & $S-1$ & $S-2$ & $s-3$ & $\overline{A-4}$ & \\
\hline $0(a)$ & 21 & 37 & 8.8 & 1.7 & 5.5 & 24 & 98 \\
\hline $\begin{array}{l}90 G \\
90 P\end{array}$ & $\begin{array}{l}25 \\
19\end{array}$ & $\begin{array}{l}29 \\
41\end{array}$ & $\begin{array}{l}10.3 \\
7.5\end{array}$ & $\begin{array}{l}1.9 \\
1.5\end{array}$ & $\begin{array}{l}5.2 \\
5.2\end{array}$ & $\begin{array}{l}27 \\
19\end{array}$ & $\begin{array}{l}98 \\
93\end{array}$ \\
\hline $\begin{array}{l}\text { 9LG } \\
\text { 9LP }\end{array}$ & $\begin{array}{l}25 \\
14\end{array}$ & $\begin{array}{l}32 \\
45\end{array}$ & $\begin{array}{l}9.4 \\
7.8\end{array}$ & $\begin{array}{l}1.8 \\
1.5\end{array}$ & $\begin{array}{l}5.7 \\
6.0\end{array}$ & $\begin{array}{l}26 \\
23\end{array}$ & $\begin{array}{r}100 \\
97\end{array}$ \\
\hline $\begin{array}{l}180 G \\
180 P\end{array}$ & $\begin{array}{l}14 \\
24\end{array}$ & $\begin{array}{l}44 \\
37\end{array}$ & $\begin{array}{l}9.9 \\
7.8\end{array}$ & $\begin{array}{l}1.9 \\
1.8\end{array}$ & $\begin{array}{l}5.2 \\
5.5\end{array}$ & $\begin{array}{l}24 \\
20\end{array}$ & $\begin{array}{l}99 \\
96\end{array}$ \\
\hline $\begin{array}{l}18 \mathrm{LG} \\
18 \mathrm{LP}\end{array}$ & $\begin{array}{l}12 \\
17\end{array}$ & $\begin{array}{l}44 \\
39\end{array}$ & $\begin{array}{l}8.8 \\
6.8\end{array}$ & $\begin{array}{l}2.3 \\
1.9\end{array}$ & $\begin{array}{l}5.7 \\
5.7\end{array}$ & $\begin{array}{l}25 \\
25\end{array}$ & $\begin{array}{l}98 \\
95\end{array}$ \\
\hline $\begin{array}{l}36 \mathrm{DG} \\
36 \mathrm{DP}\end{array}$ & $\begin{array}{l}24 \\
29\end{array}$ & $\begin{array}{l}31 \\
24\end{array}$ & $\begin{array}{l}9.4 \\
8.1\end{array}$ & $\begin{array}{l}2.0 \\
2.2\end{array}$ & $\begin{array}{l}4.5 \\
5.8\end{array}$ & $\begin{array}{l}25 \\
25\end{array}$ & $\begin{array}{l}96 \\
94\end{array}$ \\
\hline $\begin{array}{l}36 \mathrm{LG} \\
36 \mathrm{LP}\end{array}$ & $\begin{array}{l}20 \\
30\end{array}$ & $\begin{array}{l}36 \\
27\end{array}$ & $\begin{array}{l}7.5 \\
6.4\end{array}$ & $\begin{array}{l}2.8 \\
2.0\end{array}$ & $\begin{array}{l}5.9 \\
6.4\end{array}$ & $\begin{array}{l}24 \\
22\end{array}$ & $\begin{array}{l}96 \\
94\end{array}$ \\
\hline
\end{tabular}

(a) Number of exposure hours in the darkness (D) or light (L) on glass (G) or paper (P) 
TABLE 8. Concentrations of Components Identified in the Amine-Rich, S-2 Fractions of SRC-II Fuel,0il Blend Exposed to Air on Paper in Darkness or in $1.37 \mathrm{~kW} / \mathrm{m}^{2}$ of Simulated Sunlight for Various Time Periods. (All values in units of $\mu \mathrm{g} / \mathrm{g}$ of SRC liquid.)

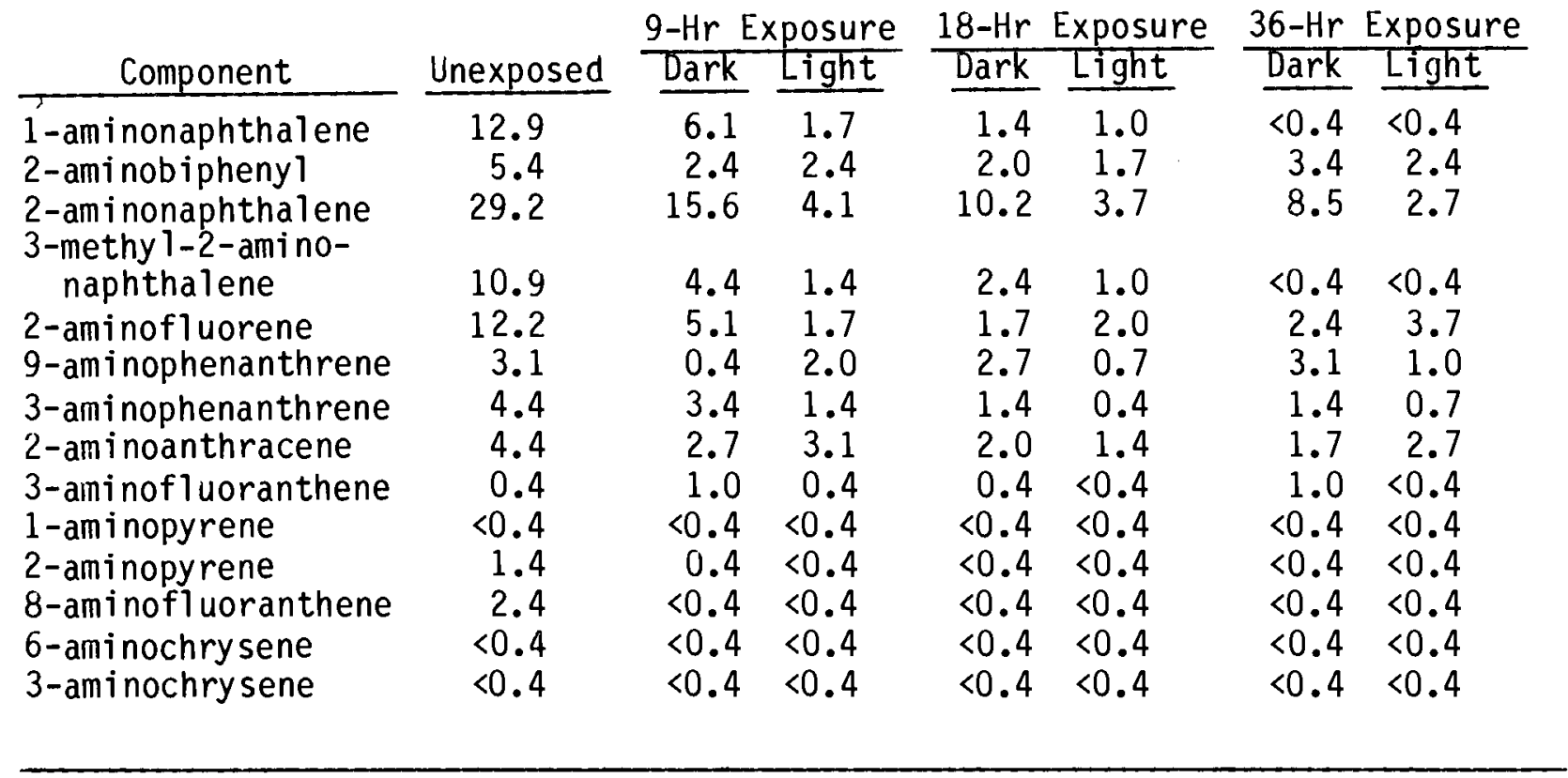

TABLE 9. Concentrations of Components Identified in the Amine-Rich, S-2 Fractions of SRC-I Process Solvent Exposed to Air on Paper in Darkness or in $1.37 \mathrm{~kW} / \mathrm{m}^{2}$ of Simulated Sunlight for Various Time Periods. (All values in units of $\mu \mathrm{g} / \mathrm{g}$ of SRC liquid.)

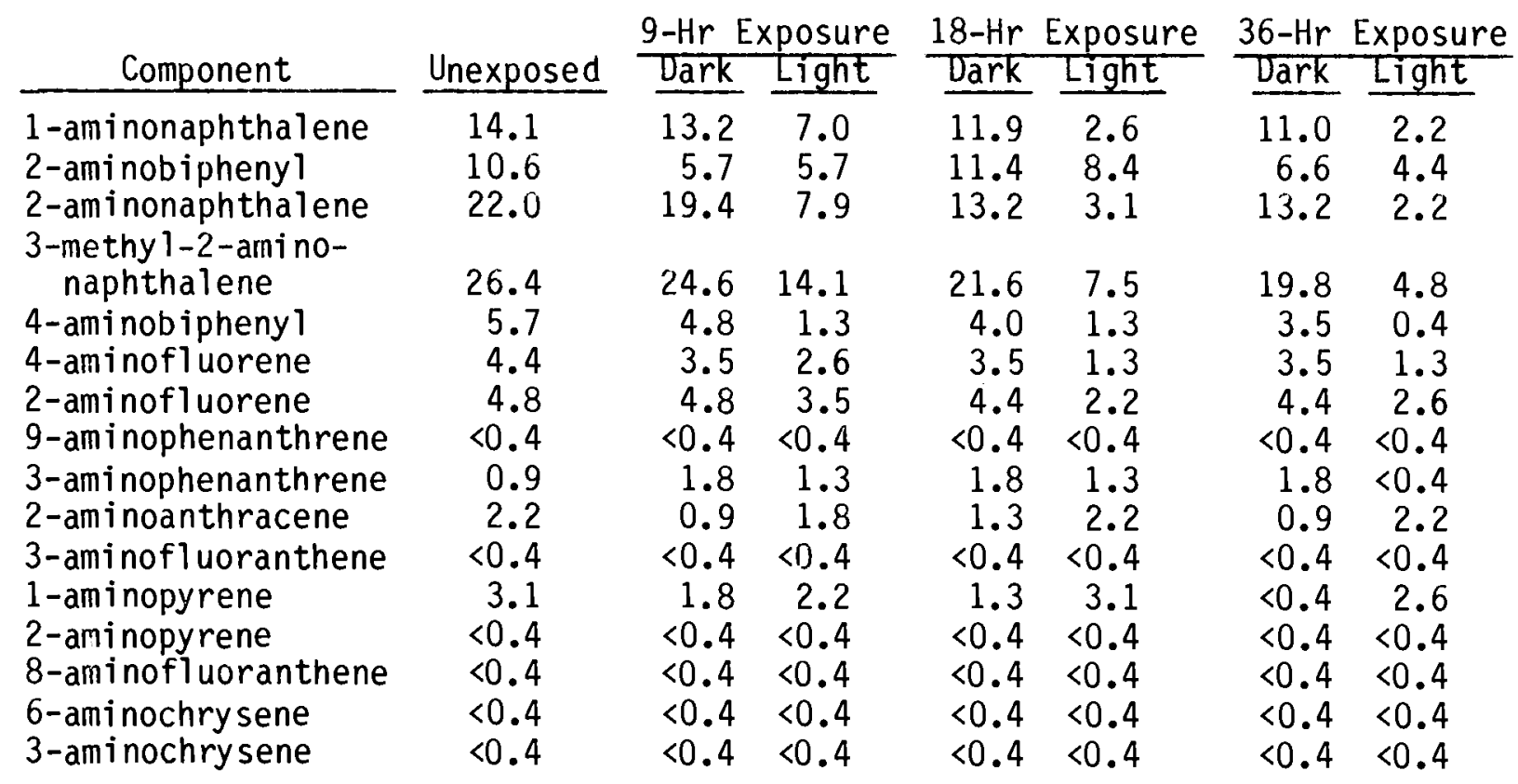




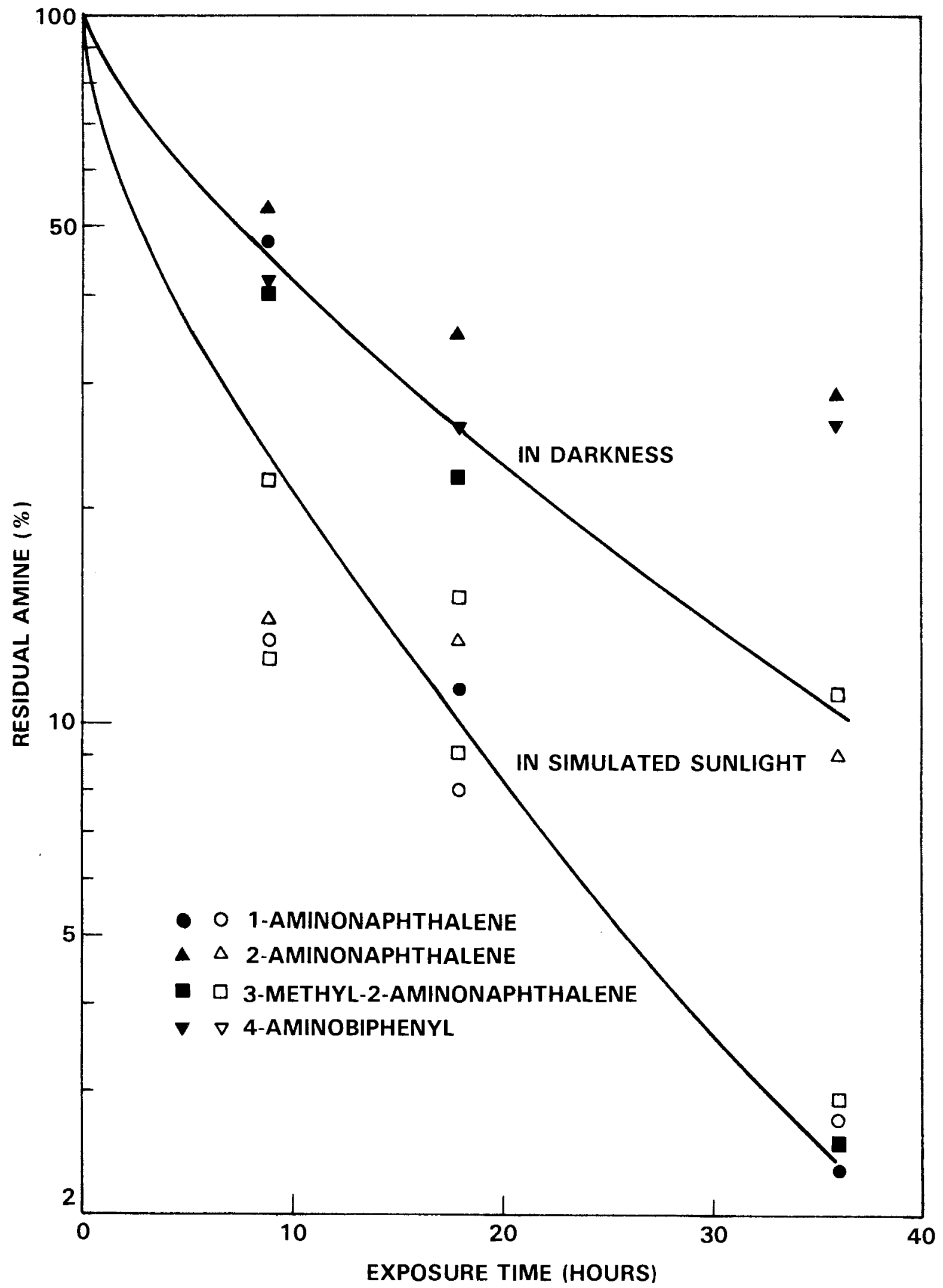

FIGURE 4. Disappearance of Representative Amines in the S-2 Fraction of SRC-II Fuel 0il Blend as a Function of Exposure Time to Air on Paper 


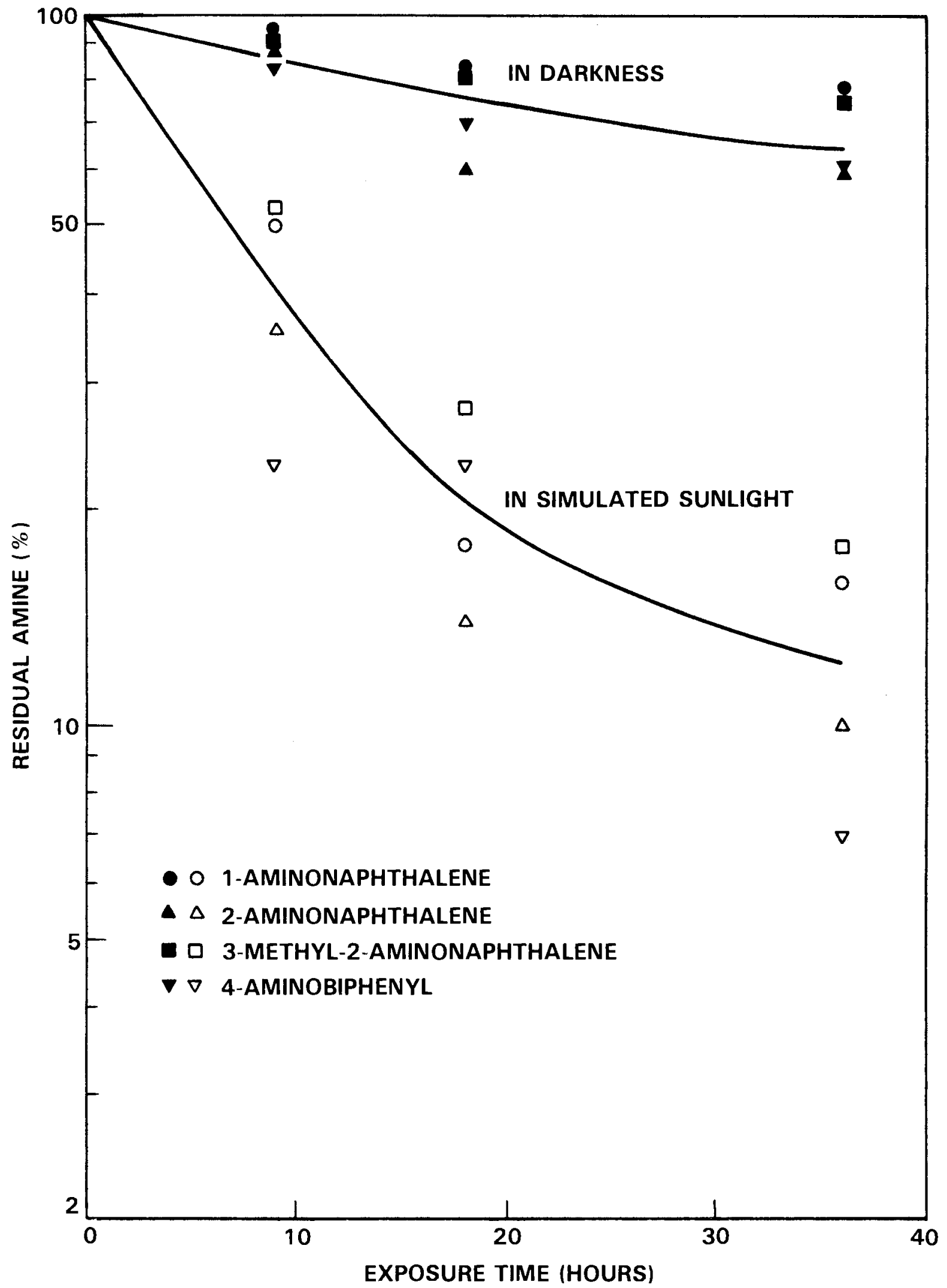

FIGURE 5. Disappearance of Representative Amines in the S-2 Fraction of SRC-I Process Solvent as a Function of Exposure Time to Air on Paper 


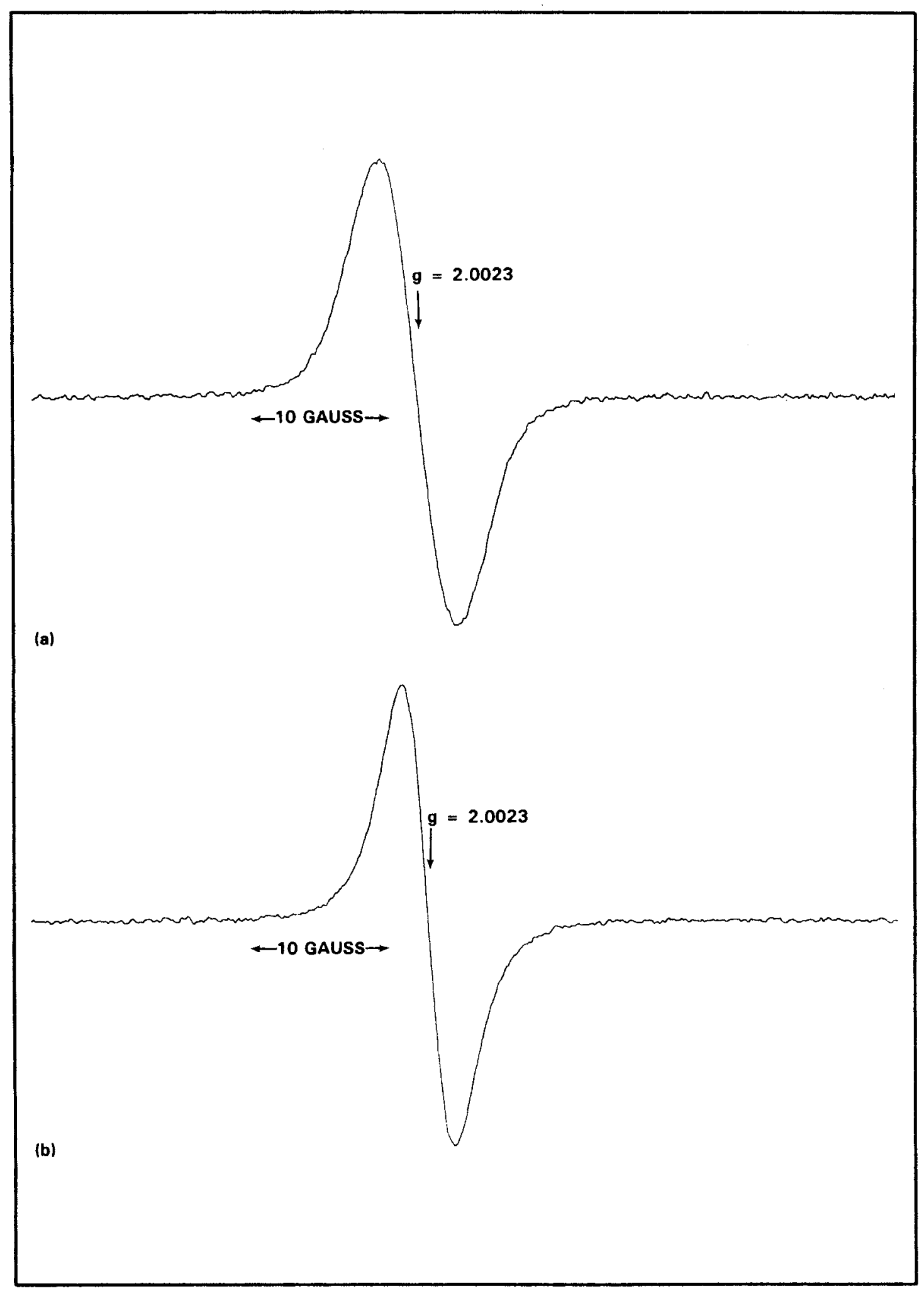

FIGURE 6. Electron Spin Resonance Spectra of (a) SRC-II Fuel $0 i 1$ Blend and (b) SRC-I Process Solvent as 10\% Solutions in Toluene

20 
at a y-value very close to 2.0023 , the value characteristic of organic free radicals and charge-transfer complexes. The concentrations of unpaired electrons in the fuel $0 i 1$ blend and the process solvent were $4.6 \times 10^{16}$ and $5.2 \times$ $10^{16}$, respectively. Possible contributions to this signal by paramagnetic organo-metallic compounds containing transition metals were examined by energydispersive X-ray fluorescence spectrometry. The concentrations of some of these metals are listed in Table 10. Those whose concentrations were near or exceeded $5 \times 10^{16}$ atoms/g could account for at least part of the spectra. However, these species do not generally show a singlet absorption band at $\mathrm{g}=$ 2.0023, and it was concluded that they probably did not contribute to the spectra.

In simulated sunlight, the total concentration of paramagnetic species in each coal liquid increased initially, then decreased with continued exposure. This pattern is indicative of free-radical formation and can be seen in data for the fuel oil blend shown in Figure 7. These data were obtained by exposing solutions of the coal liquids in the apparatus shown in Figure 1, then transferring the solutions to the spectrometer. The initial increase in concentration of radicals in the process solvent was not seen by this technique because the photo-induced radical disappeared too rapidly. It was observed, however, by illuminating the solution of process solvent through the slotted window of the spectrometer's microwave cavity. These results are shown in Figure 8.

TABLE 10. Concentrations of Metals in Coal Liquids

\begin{tabular}{|c|c|c|c|c|}
\hline & \multicolumn{2}{|c|}{ SRC-II Fuel Oil Blend } & \multicolumn{2}{|c|}{ SRC-I Process Solvent } \\
\hline & $(\mu \mathrm{g} / \mathrm{g})$ & $\left(10^{16}\right.$ atoms $\left./ g\right)$ & $(\mu \mathrm{g} / \mathrm{g})$ & $\left(10^{16}\right.$ atoms $\left./ \mathrm{g}\right)$ \\
\hline $\mathrm{Ti}$ & $<5$ & $<6$ & 8 & 10 \\
\hline V & $<4$ & $<4$ & $<3$ & $<3$ \\
\hline $\mathrm{Cr}$ & $<3$ & $<3$ & 6 & 7 \\
\hline Mn & $<2$ & $<2$ & $<2$ & $<2$ \\
\hline $\mathrm{Fe}$ & 16 & 17 & 77 & 81 \\
\hline Co & $<1$ & $<1$ & $<1$ & $<1$ \\
\hline $\mathrm{Ni}$ & $<1$ & $<1$ & 1 & 1 \\
\hline $\mathrm{Cu}$ & 4 & 4 & $<1$ & $<1$ \\
\hline
\end{tabular}




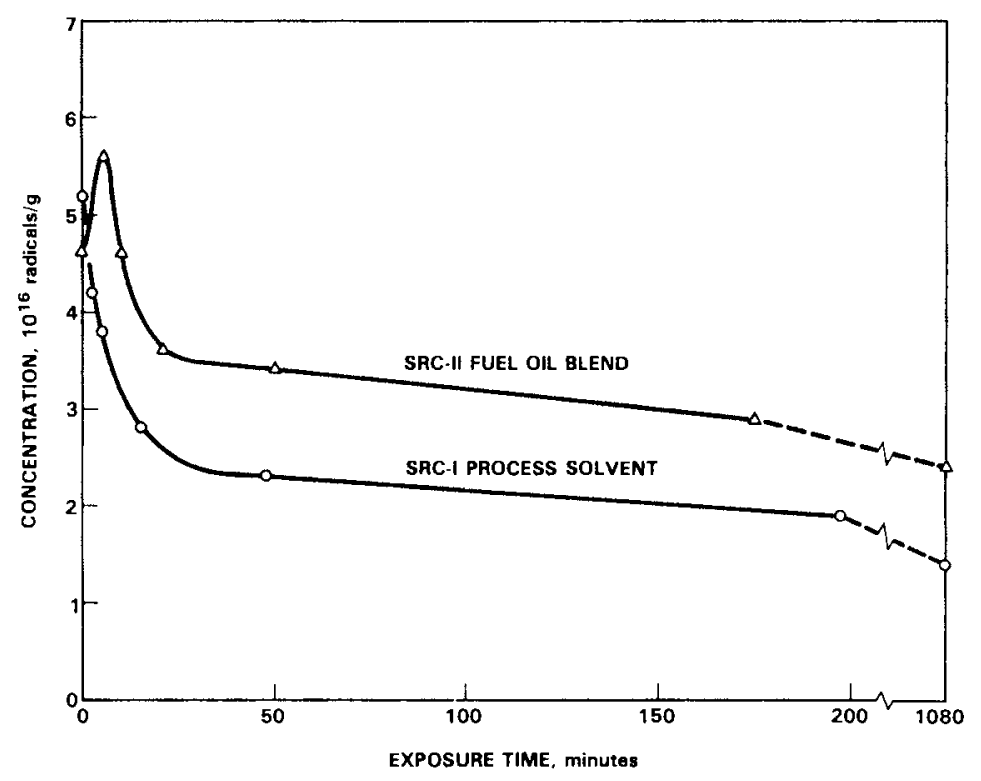

FIGURE 7. Radical Concentrations in $10 \%$ Solutions of Coal Liquids in Toluene as a Function of Exposure Time to Air in Simulated Sunlight

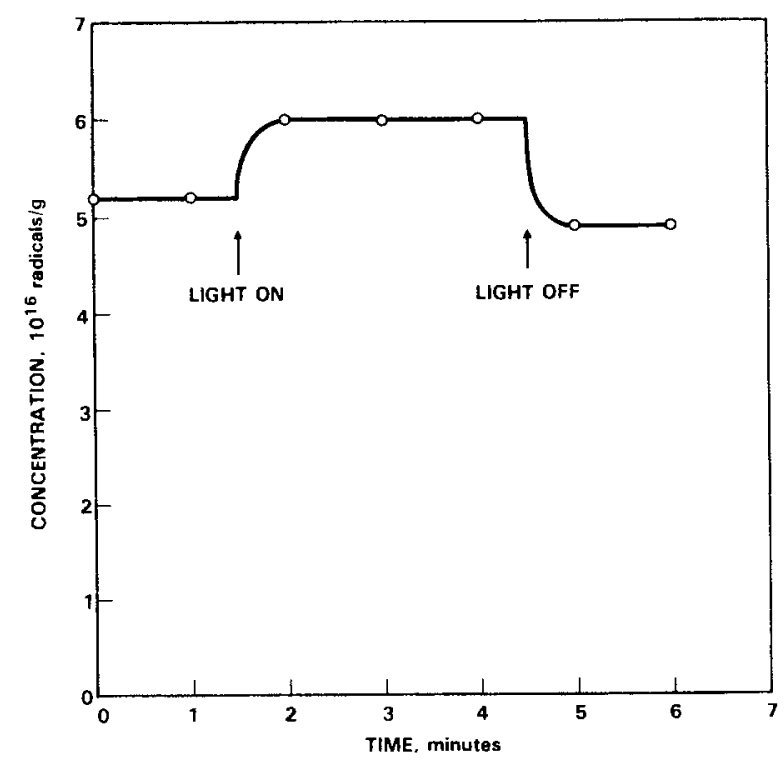

FIGURE 8. Radical Concentration in a 10\% Solution of SRC-I Process Solvent in Toluene as a Function of Exposure Time to Air in Simulated Sunlight 
In darkness, the concentrations of paramagnetic species in both liquids slowly decreased with time. This is shown in Figure 9. Comparison of these data with those shown in Figure 7 shows that the concentrations decreased more rapidly in simulated sunlight.

Paramagnetic species were detected in all but the A-1 fractions of the untreated SRC liquids; their concentrations are listed in Table 11. It seemed unlikely that these fractions could contain both electron donors and electron

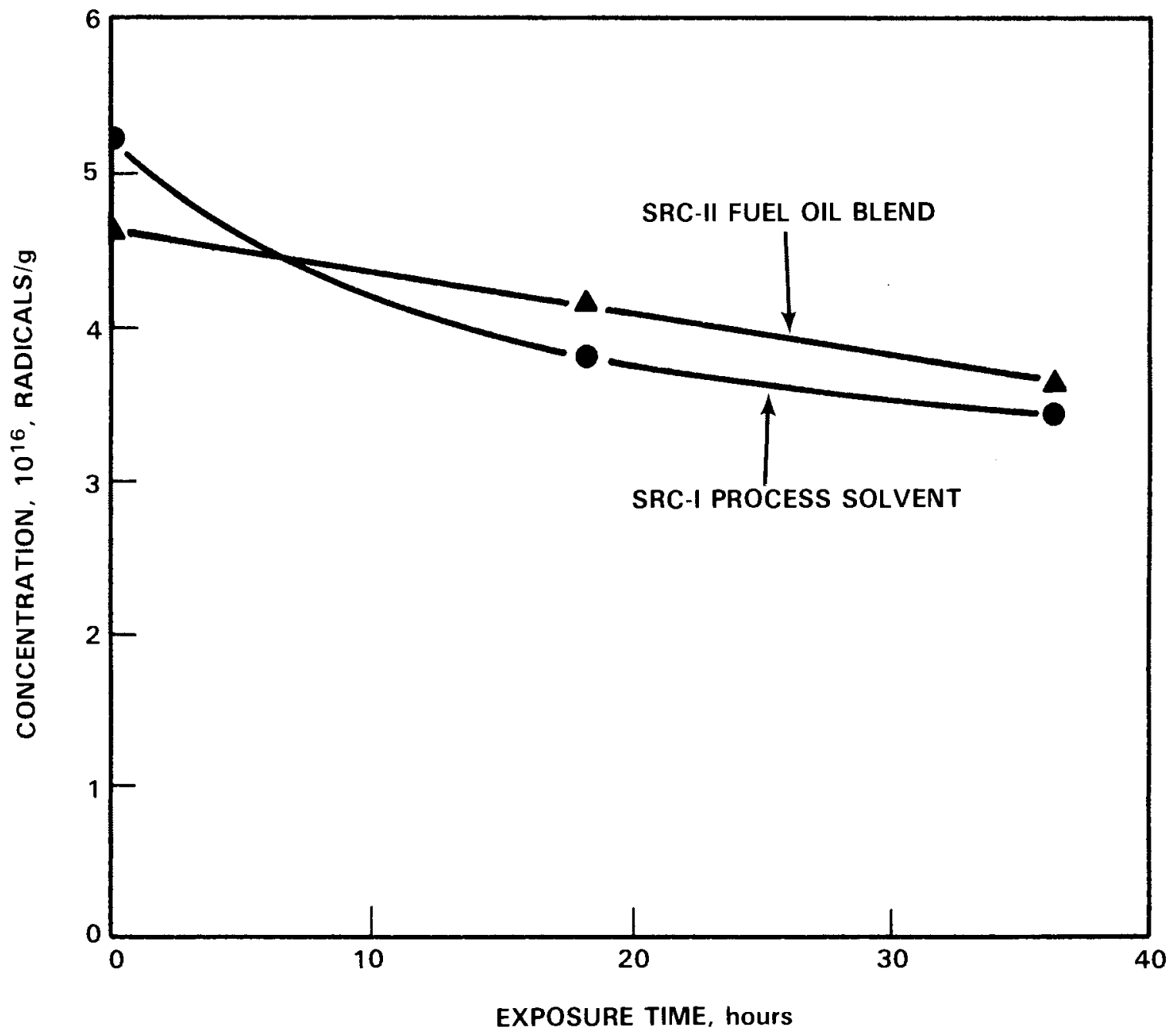

FIGURE 9. Concentrations of Paramagnetic Species in 10\% Solutions of SRC Liquids in Toluene as a Function of Exposure Time to Air in Darkness 
TABLE 11. Concentrations of Organic Free Radicals in Fractions from Samples of Untreated Coal Liquids (All values in units of radicals/g.)

\begin{tabular}{ccc} 
Fraction & SRC-II Fuel 011 Blend & SRC-I Process Solvent \\
\cline { 1 - 2 } A-1 & $<1 \times 10^{13}$ & $<1 \times 10^{14}$ \\
A-2 & $2.4 \times 10^{15}$ & $4.0 \times 10^{15}$ \\
S-1 & $1.6 \times 10^{16}$ & $4.6 \times 10^{16}$ \\
S-2 & $1.2 \times 10^{17}$ & $1.7 \times 10^{17}$ \\
S-3 & $1.5 \times 10^{16}$ & $5.1 \times 10^{16}$ \\
A-4 & $5.0 \times 10^{16}$ & $2.1 \times 10^{16}$
\end{tabular}

acceptors capable of forming a charge-transfer complex. We concluded, therefore, that the species were organic free radicals. The $\mathrm{S}-2$ fractions showed the highest radical concentrations by factors of at least 3 . Also, the concentrations of radicals in these fractions were reduced by exposing the SRC liquids to air, as shown in Table 12. These reductions were accelerated by simulated sunlight as were the mutagenicities of the samples.

In order to learn more about possible sources of ESR absorption in coal liquids, a solution of a representative amino-PAH, 2-aminoanthracene, was prepared in toluene and examined both before and after successive exposures to $1.37 \mathrm{~kW} / \mathrm{m}^{2}$ of simulated sunlight. The solution was exposed outside the spectrometer's microwave cavity, and the results are shown in Figure 10. The concentration of 2-aminoanthracene, determined by gas chromatography, decreased rapidly at this light intensity. Initially, the amine solutions contained no detectable radicals, but the radical concentration increased with illumination, then decreased below the limit of detection within 10 minutes. The spectrum of

TABLE 12. Concentrations of Organic Free Radicals in the Amine-Rich, S-2 Fractions from Samples of Coal Liquids Exposed to Air on Glass or Paper in Darkness or in $1.37 \mathrm{~kW} / \mathrm{m}^{2}$ of Simulated Sunlight (All values in units of $10^{17}$ radicals/g.)

\begin{tabular}{|c|c|c|c|c|c|c|c|c|}
\hline \multirow{3}{*}{$\begin{array}{l}\text { Time } \\
(\mathrm{hr})\end{array}$} & \multicolumn{4}{|c|}{ SRC-II Fuel oil Blend } & \multicolumn{4}{|c|}{ SRC-I Process Solvent } \\
\hline & Glass & Support & Paper & Support & Glass & Support & Paper & Support \\
\hline & Dark & Light & Dark & Light & Dark & Light & Dark & Light \\
\hline 0 & 1.2 & 1.2 & 1.2 & 1.2 & 1.7 & 1.7 & 1.7 & 1.7 \\
\hline 9 & 0.8 & 0.8 & 0.8 & 0.8 & 1.6 & 1.4 & 1.7 & 1.3 \\
\hline 18 & 0.8 & 0.6 & 0.5 & 0.4 & 1.4 & 0.8 & 1.2 & 0.9 \\
\hline 36 & 0.7 & 0.6 & 0.5 & 0.5 & 1.1 & 0.8 & 0.9 & 0.4 \\
\hline
\end{tabular}


the radical derived from photolyzing 2-aminoanthracene was resolved into 19 lines (Figure 11). However, additional efforts to increase resolution are needed to distinguish the chemical structure of the radical unambiguously. Identification would require resolution sufficient to correlate the intensities of the hyperfine lines with those anticipated from candidate chemical structures.

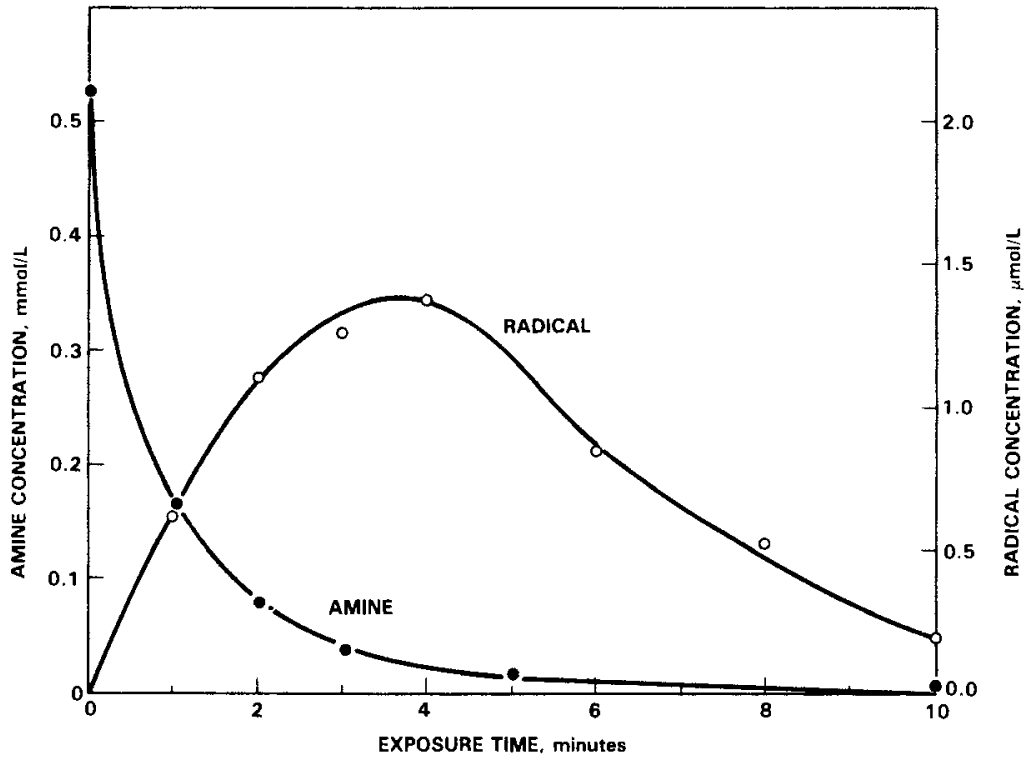

FIGURE 10. Concentrations of 2-Aminoanthracene and Its Free-Radical Product as Functions of Time in Air and Simulated Sunlight

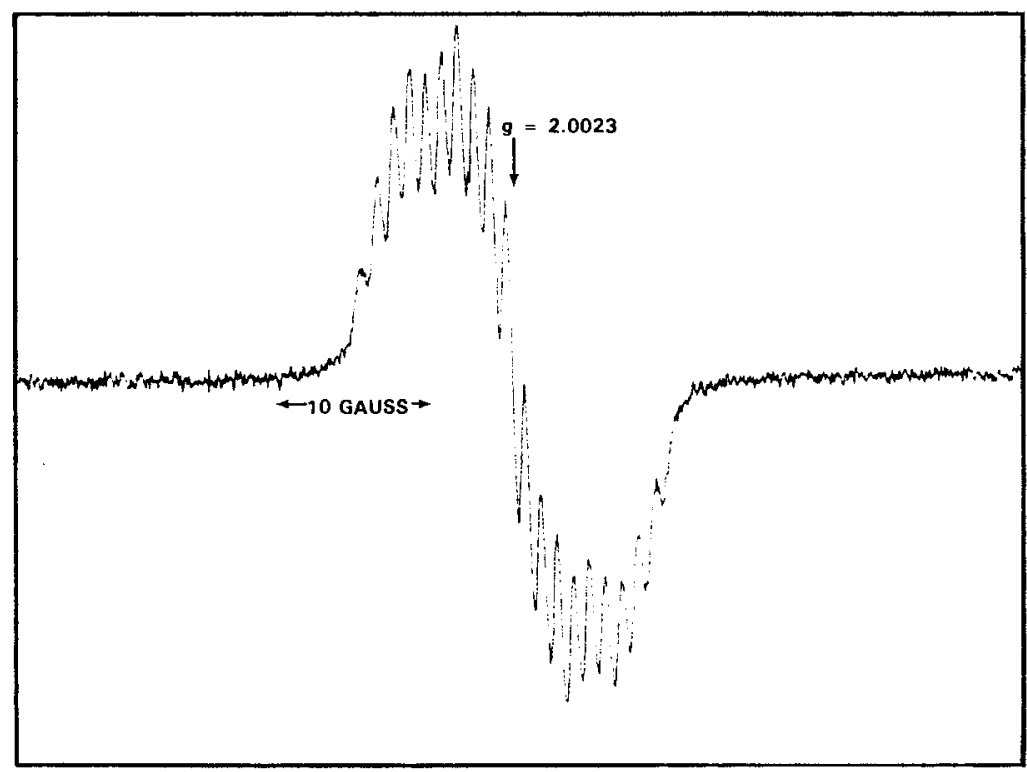

FIGURE 11. Electron Spin Resonance Spectrum of the Free Radical Formed by Photolysis of 2-Aminoanthracene in Air and Simulated Sunlight 


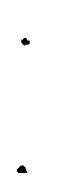

列 


\section{DISCUSSION}

The results of this investigation indicate that the microbial mutagenicities of SRC-II fuel oil blend and SRC-I process solvent may be expected to gradually decrease if these materials are spilled out of doors. Exposure of the liquids to air and simulated sunlight for several hours reduced the concentrations of the amine components, the predominant source of mutagenicity; and any new mutagens resulting from the exposure were relatively ineffective, as measured by microbial mutagenicity assays using S. typhimurium TA98. However, this assay has been reported to be less sensitive than mammalian-cell systems to potential mutagens in the neutral, aromatic (A-2) fractions of the SRC liquids (Mahlum et al. 1983). Thus, one cannot be sure that all of the potential heal th hazards of these materials are reduced by exposure to air and sunlight.

In these experiments, the samples were purposely exposed as thin layers in order to obtain uniform illumination and rapid penetration by oxygen. In contrast, the mutagenicities of coal liquids stored under nitrogen gas in the dark have been shown to be relatively constant with time, (Wright and Weimer 1984). These results indicate that the rate of decrease in mutagenicity will be enhanced by good contact between the spilled liquids and both air and sunlight.

The contrast between the results of this study and those showing a mutagenicity-enhancing effect of near-ultraviolet light on coal liquids suggests that short-lived, photo-induced species, e.g., organic free radicals, may be formed in these liquids and that such species can be mutagenic. In this study, the products of exposure were tested in the mutagenicity assays several days after they were formed. In studies where near-ultraviolet light enhanced the mutagenicity of coal liquids and other fuel oils (Larson et al. 1977; Barnhart and Cox 1980; Strniste and Brake 1981; Strniste and Chen 1981; Chen and Strniste 1982; Strniste et al. 1982a, 1982b; Selby et al. 1983), the test material was illuminated while in contact with the biological organism. This latter protocol gives any short-lived photolysis products, whether derived from amines or other organic components, more opportunity to diffuse to the deoxyribonucleic acid of the organism and to initiate mutagenesis before reacting with air or other substances in their surroundings. 
ESR measurements showed that short-lived organic free radicals were indeed formed by exposure of SRC-II fuel oil blend and SRC-I process solvent to simulated sunlight. The concentration of photo-induced radicals attained its maximum value within a few minutes after illumination began, then decreased rapidly below the background concentration of more stable paramagnetic species in the liquids. The chemical structures of the photo-induced radicals were not identified; but the kinetics of their formation and decay, as well as the linewidth and g-value of their ESR absorption signal, were very similar to those for radicals produced by photo-oxidation of 2-aminoanthracene in solution.

Detection of stable paramagnetic species in these coal liquids provides further information about their compositions and potential reactivities. It was particularly interesting to find organic free radicals in all but one of the chemical-class fractions from both coal liquids. The apparent stabilities of these radicals may be due to their limited chemical reactivities in glass containers exposed to ordinary laboratory light. Stability may also be due to a dynamic process of radical formation and destruction in which only a steadystate concentration of radicals is observed.

Other bituminous materials have been shown to contain both organic free radicals and charge-transfer complexes (Yen and Young 1973). Charge-transfer complexes can be distinguished from organic free radicals by the different effects of temperature on their ESR spectra (Alger 1968), and such measurements are planned for future research in this project. In any case, the presence of organic free radicals in a liquid raises the possibility of radical-mediated chain polymerizations which may cause the formation of undesirable gums and other sediments in these liquids (Frankenfeld et al. 1983).

The decrease in mutagenicities of the amine-rich, $\dot{S}-2$ fractions was accompanied by reductions in the concentrations of amino-PAH and organic free radicals in these fractions. Both the amino-PAH and their free radicals may contribute to the mutagenicities of the fractions. However, in view of the enhanced mutagenicity of coal liquids in contact with biological organisms exposed to near-ultraviolet light, it seems likely that the radicals are the ultimate mutagens and that the amines act as reservoirs for their production by means of auto-oxidation or photo-oxidation. It is clear, however, that all 
radicals are not mutagenic, since some fractions of the SRC liquids, e.g., the A-2, S-1 and A-4 fractions, with substantial radical concentrations, showed no response in the microbial mutagenicity assay with $\underline{S}$. typhimurium TA98. 
. .

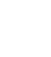

• 


\section{CONCLUSIONS}

It was concluded that if SRC-I I fuel oil blend or SRC-I process solvent is spilled out of doors, its microbial mutagenicity may be expected to gradually decrease. The rate of decrease will depend on the access of the liquids to air and sunlight and will be enhanced by conditions that promote uniform illumination and rapid diffusion of oxygen into all parts of the spilled material.

It was also concluded that organic free radicals may be important intermediates in the mutagenic action of amino-PAH. Formation of radicals would explain the mutagenicity-enhancing effect of near-ultraviolet light on coal liquids in contact with biological organisms during illumination. The eventual photodegradation of these radicals and their amine precursors would explain the decrease in mutagenicities of the SRC liquids examined in this investigation. 
-

-

$-$

$-$ 


\section{REFERENCES}

Alger, R. S. 1968. Electron Paramagnetic Resonance: Techniques and Applications. Wiley-Interscience, New York.

Ames, N., J. McCann and E. Yamasaki. 1975. "Methods for Detecting Carcinogens and Mutagens with the Salmonella/Mammalian-Microsome Mutagenicity Test." Mutat. Res. 31:347-364.

Barnhart, B. J. and S. H. Cox. 1980. "Mutation of Chinese Hamster Cells by Near-UV Activation of Promutagens." Mutation Res. 72:135-142.

Chen, D. J. and G. F. Strniste. 1982. "Cytotoxic and Mutagenic Properties of Shale 0il Byproducts II. Comparison of Mutagenic Effects of Five Genetic Markers Induced by Retort Process Water Plus Near U1traviolet Light in Chinese Hamster Ovary Cells". Environ. Mutagen. 4:457-467.

Frankenfeld, J. W., W. F. Taylor and D. W. Brinkman. 1983. "Storage Stability of Synfuels from 0il Shale. General Features of Sediment Formation in Model Fuel Systems". Ind. Eng. Chem. Prod. Res. Dev. 22:608-614.

Henglein, A., M. Boysen and W. Schnabel. 1957. "The Decomposition of Methyl Esters of Polymethylacrylic Acid in Solutions Exposed to Co-Gamma Radiation". Z. Physik. Chem. (Wiesbaden). 10:137-155.

Larson, R. A., L. L. Hunt and D. W. Blakenship. 1977. "Formation of Toxic Products from a No. 2 Fuel $0 i 1$ Photooxidation". Environ. Sci. Tech. 11:492496.

Later, D. W., M. L. Lee, K. D. Bartle, R. C. Kong and D. L. Vassilars. 1981. "Chemical Class Separation and Characterization of Organic Compounds in Synthetic Fuels". Anal. Chem. 53:1612-1620.

Later, D. W., M. L. Lee and B. W. Wilson. 1982. "Selective Detection of Amino Polycyclic Arornatic Compounds in Solvent Refined Coal". Anal. Chem. 54:117123.

Mahlum, D. D. 1983. "Initiation Promotion Studies with Coal-Derived Liquids". J. Appl. Tox. 3:31-34.

Mahlum, D. D., M. E. Frazier, R. A. Pelroy and R. A. Renne. 1983. Comparison of In Vitro and In Vivo Studies with Coal Liquids from the SRC-II Process. PNL-4836, Pacific Northwest Laboratory, Richland, Washington, (NTIS) Springfield Virginia.

Mahlum, D. D. and B. W. Wilson. 1983. "Components Responsible for Skin Tumor Initiating Activity in Coal Liquids. The Toxicologist. 3:49. 
Pelroy, R. A. and M. R. Petersen. 1981. "Mutagenic Characterization of Synthetic Fuel Materials by the Ames/Salmonella Assay System". Mutat. Res. $90: 309-320$.

Pelroy, R. A. and B. W. Wilson. 1981. "Relative Concentrations of Polyaromatic Primary Amines and Azaarenes in Mutagenically Active Nitrogen Fractions from a Coal Liquid." Mutat. Res. 90:321-335.

Sanders, R. W., K. B. 0lsen, W. C. Weimer and K. K. Nielson. 1983. "Multielement Analysis of Unweighed $0 i 1$ Samples by X-Ray Fluorescence Spectrometry with Two Excitation Sources". Anal. Chem. 55:1911-1914.

Selby, C, J. Calkins and H. Enoch. 1983. "Detection of Photomutagens in Natural and Synthetic Fuels." Mutation Res. 124:53-60.

Stair, R. and H. T. Ellis. 1968. "The Solar Constant Based on New Spectral Irradiance Data from 310-530 Nanometers". J. Appl. Meterology. 7:635-643.

Strniste, G. F., J. M. Bingham, R. T. Okinaka and D. J. Chen. 1982a. "Genotoxicity Induced in Cultured Hamster Cells Exposed to Natural or Synthetic Crude 0ils and Near Ultraviolet Light". Tox. Letts. 13:163-167.

Strniste, G. F. and R. J. Brake. 1981. "Cytotoxicity in Human Skin Fibroblasts Induced by Photoactivated Polycyclic Aromatic Hydrocarbons, "In Polynuclear Aromatic Hydrocarbons: Fifth International Symposium on Chemical Analysis and Biological Fate, eds. M. Cooke and A. J. Dennis, pp. 109-118. Battelle Press, Columbus, Ohio.

Strniste, G. F. and D. J. Chen. 1981. "Cytotoxic and Mutagenic Properties of Shale $0 i 1$ Byproducts I. Activation of Retort Process Waters with Near Ultraviolet Light". Environ. Mutagen. 31:221-231.

Strniste, G. F., D. J. Chen and R. T. Okanaka. 1982b. "Genotoxic Effects of Sunlight-Activated Waste Water in Cultured Mammalian Cells". J. Nat. Cancer Inst. 69:199-203.

Wilson, B., R. Pelroy and J. Cresto. 1980. "Identification of Primary Aromatic Amines in Mutagenically Active Subfractions from Coal Liquefaction Materials". Mutat. Res. 79:193-202.

Wright, C. W. and W. C. Weimer. 1984. Chemical and Biological Stability of Solvent-Refined Coal Liquids. PNL-4962, Pacific Northwest Laboratory, Richland, Washington, (NTIS) Springfield, Virginia.

Yen, T. F. and D. K Young. 1973. "Spin Excitations of Bitumems". Carbon $11: 33-41$. 
No. of

Copies

OFFSITE

27 DOE Technical Information Center

E. L. Alpen

Lawrence Berkeley Laboratory University of California

Building 90, Room 2056

No. 1 Cyclotron Road

Berkeley, CA 94720

L. D. Attaway

1005 A Street

Suite 405

San Rafael, CA 94901

N. F. Barr

ER-73, GTN

U.S. Department of Energy

Washington, DC 20545

J. Batchelor

FE-43, GTN

U.S. Department of Energy

Washington, DC 20545

D. L. Bauer

Acting Assistant Secretary

for Fossil Energy

FE-1, FORSTL

U.S. Department of Energy

Washington, DC 20585

H. L. Bergman

University of Wyoming

Laramie, WY 82071

R. W. Biles

Exxon Corporation

Research and Environmental

Health Division

Medical Department

P.0. Box 235

East Millstone, NJ 08873
No. of

Copies

J. R. Blair

ER-73, GTN

U.S. Department of Energy

Wasington, DC 20545

V. P. Bond

Brookhaven National Laboratory

Upton, Long Island, NY 11973

R. G. Boykin

Catalytic, Inc.

P.0. Drawer 239

Wilsonville, AL 35186

J. E. Bratina, Jr.

Environmental Research and Technology, Inc.

601 Grant Street

Porter Building, 10th Floor

Pittsburgh, PA 15219

A. Brink

SASOL Technology

(Proprietary), Ltd.

57 Commissioner Street

P.0. Box 5486

Johannesburg 2000

REPUBLIC OF SOUTH AFRICA

P. E. Brubaker

Exxon Corporation

Research and Environmental

Health Division

Medical Department

P.0. Box 235

East Millistone, NJ 08873

P. Buh1

FE-43, GTN

U.S.Department of Energy

Washington, DC 20545 
No. of

Copies

H. H. Bulkowski

Catalytic, Inc.

Centre Square West

1500 Market Street

Philadelphia, PA 19102

F. P. Burke

Conoco Coal Development Co. 4000 Brownsville Road

Library, PA 15129

J. A. Carrol, Capt., USA

Medical Bioengineering R\&D Laboratory

Ft. Detrich, MD 21701

C. E. Carter

Scientific Director

National Institute of

Environmental Health Sciences

P.0. Box 12233

Research Triangle Park, NC 27709

M. Chartock

Science \& Public

Policy Program

Norman, OK 73019

C. T. Chen

OSHA

U.S. Departinent of Labor

200 Constitution Avenue, NW

Washington, DC 20210

P. Cho

ER-73, GTN

U.S. Department of Energy

Washington, DC 20545

A. V. Colucci

A. V. Colucci \& Associates, Inc. 15305 Calle Enrique, Suite D

Morgan Hill, CA 95037

4 K. E. Cowser

Oak Ridge National Laboratory

P.0. Box $X$

Oak Ridge, TN 37830
No. of

Copies

$$
\begin{aligned}
& \text { G. Day } \\
& \text { Kentucky Division of } \\
& \text { Air Pollution Control } \\
& 18 \text { Riley Rd. } \\
& \text { Frankfort, KY } 40601
\end{aligned}
$$

2 Department of Library and Archives

James Nelson, Librarian

Box 537 , Berry $\mathrm{Hill}$

Frankfort, KY 40602

2 DOE Public Document Room

Attn: Mr. R. A. Evans

Room G-298, Federal Building

P.0. Box E

Oak Ridge, TN 37830

2 DOE Public Reading Room, FOI

Room IE-180, Forrestal Building

1000 Independence Avenue, SW

Washington, DC 20585

2 DOE Technical Information Center

Customer Services Branch

P.0. Box 62

Oak Ridge, TN 37830

2 DOE Public Document Room

Room G-208

Oak Ridge Federal Building

Oak Ridge, TN 37830

2 DOE Public Reading Room

Room GA-142

Forrestal Building

1000 Independence Avenue, SW

Washington, DC 20585

B. Z. Drozdowicz

International Coal Refining Co.

P.0. Box 2752

Allentown, PA 18001 
No. of

Copies

H. Drucker

Argonne National Laboratory 9700 South Cass Avenue

Argonne, IL 60439

C. Drummond

Pittsburgh Energy

Technology Center

P.0. Box 10940

Pittsburgh, PA 15236

25 A. P. Duhamel

ER-74, GTN

U.S. Department of Energy

Washington, DC 20545

H. E. Dunn

Indiana State University, Evansville

8600 University Boulevard

Evansville, IN 47702

M. J. Eaman

Concord Scientific Corporation

3101-B Hawthorn Road

Ottawa, Ontario, K1G-3H9

CANADA

C. W. Edington, Associate Director

Office of Health and

Environmental Research

ER-70, GTN

U.S. Department of Energy

Washington, DC 20545

H. Enoch

Kentucky Department of Energy

P.0. Box 11888

Lexington, KY 40578

J. L. Epler

Oak Ridge National Laboratory

P.0. Box $X$

Oak Ridge, TN 37830
No. of

Copies

2 Evansville \& Vanderburgh

County Public Library

Attn: Ann Pearson

22 Southeast 5 th Street

Evansville, IN 47708

J.P. Fillo

Environmental Research and

Technology, Inc.

601 Grant Street

Porter Building, 10th Floor

Pittsburgh, PA 15219

S. Foster

Eneryy and Environmental Analysis, Inc.

1111 North 19th Street

Arlington, VA 22209

L. Fradkin

Aryonne National Laboratory

Building 12

Argonne, IL 60439

R. E. Franklin

ER-75, GTN

U.S. Departinent of Energy

Washington, DC 20545

R. J. Fry

Oak Ridge National Laboratory

P.0. Box $X$

Oak Ridge, TN 37830

K: Frye

FE-40, GTN

U.S. Department of Energy

Washington, DC 20545

A. A. Galli

U.S. Environmental Protection Agency

401 M Street, SW

Washington, DC 20460 
No. of

Copies

C. W. Gehrs

Oak Ridge National Laboratory

P.0. Box $X$

Oak Ridge, TN 37830

H. Gerstenkorn

Ruhrkohle Oel und Gas GMBH

Gleiwitzer Platz 3

4250 Bottropp

FEDERAL REPUBLIC OF GERMANY

J. M. Giddings

Oak Ridge National Laboratory

P.0. Box $X$

Oak Ridge, TN 37830

G. F. Goethel

VEBA OEL AG

Postfach 45

4660 Gel senk i rchen-Buer

FEDERAL REPUBLIC OF GERMANY

L. Goldberg

Chemical Industrial

Institute of Toxicology

2109 Nancy Ann Drive

Raleigh, NC 27607

G. Goldstein

ER-74, GTN

U.S. Department of Energy

Washington, DC 20545

J. R. Gough

Catalytic, Inc.

P.0. Box 239

Wilsonville, AL 35186

J. Gray

Ashland Synthetic Fuels, Inc.

P.0. Box 391

Ashl and, KY 41101

M. D. Gray

NCB (Coal Products) Ltd.

Coal House, Lyon Rd.

Harrow, HAl 2 EX

ENGLAND
No. of

Copies

R. A. Griesemer

Oak Ridge National Laboratory

P.0. Box $X$

Oak Ridge, TN 37830

M. Guerin

Oak Ridge National Laboratory

P.0. Box $X$

Oak Ridge, TN 37830

R. M. Hamilton

FE-43, GTN

U.S. Department of Energy

Washington, DC 20545

A. Hartstein

FE-43, GTN

U.S. Department of Energy

Washington, DC 20545

L. Headley

Morgantown Energy

Technology Center

Morgantown, WV 26505

G. E. Hedstrom

FE-44, GTN

U.S. Department of Energy

Washington, DC 20545

M. G. Henry

Columbia National Fisheries

Research Laboratory

Route 1

Columbia, MO 65201

2 B. Henschel

Industrial Environmental

Research Laboratory

MD-61, U.S. EPA

Research Triangle Park, NC 27711

J. Hill

Ashland Synthetic Fuels, Inc. P.0. Box 391

Ashland, KY 41101 
No. of

Copies

R. Hill

Ashland Synthetic Fuels, Inc.

P.0. Box 391

Ashland, KY 41101

C. H. Hobbs

Lovelace Inhalation Toxicology Research Institute

P.0. Box 5890

Albuquerque, NM 87115

J. M. Holland

Chevron Environmental Health Center

P.0. Box 4054

Richmond, CA 94804

H. L. Hollister, Assistant Secretary

Environmental Protection, Safety and Emergency Preparedness

EP-1, FORSTL

U.S. Department of Energy

Washington, DC 20585

G. R. Holt

ARCO Coal Company

1860 North Lincoln St.

P.0. Box 5300

Denver, CO 80217

H. Hosang

VEBA OEL AG

Postfach 45

4660 Gel senkirchen-Buer

FEDERAL REPUBLIC OF GERMANY

$P$. House

EP-33, FORSTL

U.S. Department of Energy

Washington, DC 20585

W. Hubis

4031 South Magnolia Way

Denver, C0 80237
No. of

Copies

E. L. Huffman

Southern Company Services, Inc. P.0. Box 2625

Birmingham, AL 35202

S. Ikeda

Japan Coal Liquefaction Development Co., Ltd.

Rm 1115, Shuwa Kioi-Cho

TBR Bldg.

No. 7, Kōjimachi 5-chome, Chiyoda-Ku, Tokyo 102

JAPAN

H. Inhaber

Oak Ridge National Laboratory

P.0. Box $X$

Oak Ridge, TN 37830

J. C. Johnson

FE-13, GTN

U.S. Department of Energy

Washington, DC 20545

T. W. Johnson

Southern Company Services, Inc. c/o Catalytic, Inc.

P.0. Drawer 239

Wilsonville, AL 35186

W. S. Jones

FE-43, GTN

U.S. Department of Eneryy

Washington, DC 20545

L. Joseph

Hydrocarbon Research, Inc. 1313 Dolly Madison Blvd.

McLean, VA 22101

J. S. Kane, Deputy Director Office of Energy Research ER-2, FORSTL

U.S. Department of Energy

Washington, DC 20585 
No. of

Copies

C. M. Kelly

Air Products \& Chemicals, Inc. Corporate Research \& Development P.0. Box 538

Allentown, PA 18001

S. C. Lewis

Exxon Corporation

Research and Environmental

Health Division

Medical Department

P.0. Box 235

East Millstone, NJ 08873

R. R. Maddocks

Catalytic, Inc.

Centre Square West

1500 Market Street

Philadelphia, PA 19102

\section{A. W. Maki \\ Exxon Corp. \\ Research and Environinental Health Division}

P.0. Box 235

East Millstone, $\mathrm{NJ} 08873$

2 M. J. Massey

Environmental Research and Technology, Inc.

601 Grant Street

Porter Building, 10th Floor

Pittsburgh, PA 15219

H. MCCammon

ER-75, GTN

U.S Departinent of Energy

Washington, DC 20545

R. 0. Mcclellan

Lovelace Inhalation Toxicology Research Institute

P.0. Box 5890

Albuquerque, NM 87115
No. of

Copies

\author{
G. V. McGurl \\ Pittsburgh Energy \\ Technology Center \\ P.0. Box 10940 \\ Pittsburgh, PA 15236 \\ R. E. Mckee \\ Exxon Corp. \\ Research and Environmental \\ Health Division \\ P.0. Box 235 \\ East Millstone, NJ 08873 \\ P. M. Mehrle \\ Columbia National Fisheries \\ Research Laboratory \\ Route 1 \\ Columbia, M0 65201
}

M. L. Mendelsohn

Lawrence Livermore Laboratory

University of California

P.0. Box 808

Livermore, CA 94550

L. Miller

FE-42, GTN

U.S. Department of Energy

Washington, DC 20545

M. Minthorn

ER-72, GTN

U.S. Department of Energy

Washington, DC 20545

A. Moghissi

U.S. Environmental

Protection Agency

401 M Street, SW

Washington, DC 20460

2 Morgantown Public Library

373 Spruce Street

Morgantown, WV 26505 
No. of

Copies

\section{E. C. Moroni}

FE-43, GTN

U.S. Department of Energy

Washington, DC 20545

S. C. Morris

Brookhaven National Laboratory

Building 475

Upton, NY 11973

N. B. Munro

Fossil Energy Information Center Building 9207

Oak Ridye National Laboratory

P.0. Box Y

Oak Ridge, TN 37830

P. J. Musser

FE-44, GTN

U.S. Uepartment of Energy

Washington, DC 20545

M. B. Neuworth

The Mitre Corp.

1820 Dolly Madison Blvd.

McLean, VA 22102

J. Norwood

International Coal Refining Co.

P.0. Box 2752

Allentown, PA 18001

2 Owensboro-Davies

County Public Library

Attn: Alice G. Lewis

450 Griffith Avenue

Uwensboro, KY 42301

B. Pallay

National Institute for

Occupational Safety \& Health

5600 Fishers Lane

Rockville, MD 20852

M. Parmenter

Kerr-Mcliee Corporation

Kerr-Mcliee Center

Packaging \& Labeling Dept.

Ok lahoma City, OK 73125
No. of

Copies

R. M. Perhac

Electric Power Research Institute

P.0. Box 10412

Palo Alto, CA 93404

W. Piver

National Institute of Environ-

mental Health Sciences

P.0. Box 12233

Research Triangle Park, NC 27709

J. D. Potts

Cities Service Research

\& Development $\mathrm{Co}$.

Box 3908

Tulsa, OK 74102

2 J. Reafsnyder

Oak Ridge Operations

U.S. Department of Energy

P.0. Box E

Oak Ridge, TN 37830

C. Reaux

National Institute

for Occupational

Safety and Health

Room 117

944 Chestnut Ridge Road

Morgantown, WV 26504

C. A. Reilly

Argonne National Laboratory

9700 South Cass Avenue

Argonne, IL 60439

H. Retcofsky

Pittsburyh Energy Technology

Center

P.0. Box 10940

Pittsburgh, PA 15236

D. E. Rhodes

Kerr-McGee Corporation

P.0. Box 035

Crescent, OK 73028 
No. of

W. J. Rhodes

Industrial Environmental

Research Laboratory

MD-61, US EPA

Research Triangle Park, NC 27711

C. R. Richmond

Oak Ridge National Laboratory

P.0. Box X

Oak Ridge, TN 37830

T. C. Ruppel

Pittsburgh Energy Technology Center

P.0. Box 10940

Pittsburgh, PA 15236

H. D. Schindler

The Lummus Company

1515 Broad Street

Bloomfield, NJ 07003

D. K. Schmalzer

The Pittsbury \& Midway Coal Mining Co.

1720 South Bellaire Street

Denver, CO 80222

M. Schulman

ER-70, GTN

U.S. Department of Energy

Washington, DC 20545

0. J. Schwarz

Botany Department

University of Tennessee

Knoxville, TN 37916

J. W. Scott

Chevron Research Company

P.0. Box 1627

Richland, CA 94802

R. Scripsick

P.0. Box 1663, MS-986

Los Alamos, NM 87545
No. of

Copies

\author{
A. G. Sharkey \\ Pittsburgh Energy Technology \\ Center \\ P.0. Box 10940 \\ Pittsburgh, PA 15236
}

A. Shepard

American Petroleum Institute

2101 L Street, NW

Washington, DC 20037

C. Shin

TRW

1 Space Park

R42142

Redondo Beach, CA 90278

D. A. Smith

ER-7\%, GTN

U.S. Department of Energy

Washington, DC 20545

V. G. Stamoudis

Argonne National Laboratory

9700 South Cass Avenue

Argonne, IL 60439

G. E. Stapleton

ER-72, GTN

U.S. Department of Energy

Washington, DC 20545

J. Stasior

Enviro Control

11300 Rockville Pike

Rockville, MD 20852

R. J. Stern

EP-33, FORSTL

U.S. Departinent of Energy

Washington, DC 20585

J. Stetter

Argonne National Laboratory

9700 South Cass Avenue

Argonne, IL 60439 
No. of

Copies

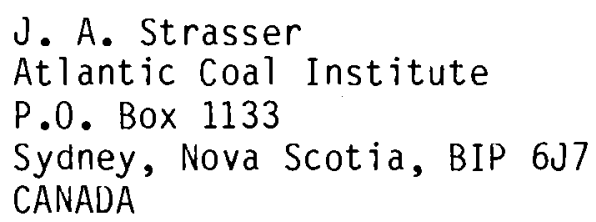

J. A. Strasser

Atlantic Coal Institute

P.0. Box 1133

Sydney, Nova Scotia, BIP $6 J 7$

CANADA

R. F. Sullivan

Chevron Research Company

P.0. Box 1627

Richinond, CA 94802

J. Talty

National Institute for

occupational Safety \& Health

5600 Fishers Lane

Rockville, MD 20852

J. W. Thiessen

Deputy Associate Director

Office of Health and

Environmental Research

ER-71, GTN

U.S. Departinent of Energy

Washington, DC 20545

G. G. Thurlow

National Coal Board

Coal Research Establishment

Stoke Orchard

Cheltenham, Glos. GL52 4RZ

ENGLAND

R. V. Trense

Exxon Corporation

Environmental Affairs Proyrams

Exxon Research \& Engineering Co.

P.0. Box 101

Florham Park, NJ 07932

3 A. W. Trivelpiece, Director

Office of Energy Research

ER-1, FORSTL

U.S. Department of Energy

Washington, DC 20585
No. of

Copies

2 University of Kentucky

Attn: J. Pivarnik

Government Publications

Department

M. L. King Library

Lexington, KY 40506

2 G. K. Vick

Exxon Research \& Engineering Co.

Clinton Township

Route 22 East

Annandale, NJ 08801

G. L. Voelz

University of California

Los Alamos Scientific Laboratory

P.0. Box 1663

Los Alamos, NM 97545

W. H. Weber

EPRI

c/o Catalytic, Inc.

P.0. Drawer 239

Wilsonville, AL 35186

2 Library

West Virginia University

Downtown Campus

Attn: C. Hamerick

Moryantown, WV 26506

4 K. Wilzbach

Aryonne National Laboratory

9800 South Cass Avenue

Argonne, IL 60439

F. E. Witiner

EP-33, GTN

U.S. Department of Energy

Washington, DC 20545

F. J. Wobber

ER-75, GTN

U.S. Department of Energy

Washington, DC 20545 
No. of

Copies

R. W. Wood

ER-74, GTN

U.S. Department of Energy

Washington, DC 20545

A. F. Yen

International Coal Refining Co.

P.0. Box 2752

Allentown, PA 18001

ONSITE

DOE Richland Operations Office

H. E. Ransom

101 Pacific Northwest Laboratory

R. L. Aabery

L. E. Anderson

W. J. Bair

R. M. Bean

C. D. Becker

F. G. Burton

W. C. Cannon

D. A. Cataldo

E. K. Chess

J. F. Cline

D. D. Dauble

W. E. Fallon

L. J. Felice

W. D. Felix

D. H. Fickeisen

M. E. Frazier

R. H. Gray (30)

P. L. Hackett

D. R. Kalkwarf

M. T. Karagianes

B. J. Kelman

J. C. Kutt

D. W. Later
No. of

Copies

R. H. Lovely

D. D. Mahlum

S. Marks

R. P. Marshall

P. J. Mellinger

J. E. Morris

0 . R. Moss

T. Nelson

J. M. Nielsen

D. E. Olesen

T. L. Page

J. F. Park (5)

R. A. Pelroy

R. W. Perkins

R. D. Phillips

H. A. Ragan

R. A. Renne

R. E. Schirmer

R. P. Schneider

D. M. Schoengold

M. R. Sikov

S. D. Sklarew

L. G. Smith

D. L. Springer

J. A. Strand

D. L. Stewart

W. L. Templeton

T. A. Toste

D. Tolley

B. E. Vaughan

M. L. Warner

W. C. Weimer

R. E. Wildung

W. R. Wiley

D. H. Willard

B. W. Wilson

C. W. Wright

Biology Publications Office

Technical Information (5)

Publishing Coordination (2) 